\title{
Türkiye'de Çeviribilim Bölümlerinde Teknoloji Edincini Kazandırmaya Yönelik Derslerin İncelenmesi
}

\section{Analysing Courses in Terms of Developing Technology Competence in the Translation Study Departments of Turkey}

\author{
Tuğçe Ören ${ }^{1}$ (D)
}

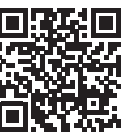

'İstanbul Üniversitesi, Sosyal Bilimler Enstitüsü, Çeviribilim Anabilim Dalı, İstanbul, Türkiye

ORCID: T.Ö. 0000-0001-5452-9100

Sorumlu yazar/Corresponding author: Tuğçe Ören (Yüksek Lisans Öğrencisi), Istanbul Üniversitesi, Sosyal Bilimler Enstitüsü, Çeviribilim Anabilim Dalı, İstanbul, Türkiye E-posta: orentugce7@gmail.com

Başvuru/Submitted: 08.08.2019

Kabul/Accepted: 20.06.2020

Atıf/Citation: Oren, T. (2020). Türkiye'de çeviribilim bölümlerinde teknoloji edincini kazandırmaya yönelik derslerin incelenmesi. Istanbul Üniversitesi Çeviribilim Dergisi - Istanbul University Journal of Translation Studies 12, (2020), 77-108

https://doi.org/10.26650/iujts.2020.12.0005

\section{Öz}

Akademik çeviri eğitiminin önemli amaçlarından biri öğrencilerin çeviri edinci kazanmalarını sağlamaya çalışmaktır. Çeviri edinci kaynak metnin anlaşılmasından erek metnin üretilmesine kadar olan süreçte çevirmenin uzmanlaşmasına ve bilinçli hareket etmesine işaret eder. Bu nedenle bir takım alt edinçleri gerektirir. Bu çalışmada çeviri edincini oluşturan bütün bu alt edinçlerden dil edinci, metin edinci, kültür edinci, araştırma edinci, konu ve uzmanlık alanı edinci ve son olarak teknoloji edinci tanımlanmıştır. Çalışmanın odak noktasını oluşturan teknoloji edincini daha anlaşıır kılmak adına, Türkçe literatürdeki teknoloji eğitimi ile ilgili çalışmalar ve yabancı kaynaklardaki çeviri edinci modelleri incelenmiştir. Teknoloji edincinin sınırlarını belirledikten sonra, Türkiye'deki 13 devlet üniversitesinde Çeviribilim veya Mütercim Tercümanlık Bölümlerinin müfredat planlarında ve ders içeriklerinde teknolojiyi konu alan dersler incelenmiştir. Bu bilgilerden yola çıkarak kaynaklarda bir alt edinç olarak yaygın şekilde anılmayan teknoloji edinci kavramını tartışmaya açmaya, lisans düzeyinde akademik çeviri eğitiminde öğrencilere teknoloji edinci kazandırma/ geliştirme konusunda öneriler sunmaya ve teknoloji edincinin çeviri edinciyle ilişkisi kurulmaya çalışılmıştır.

Anahtar kelimeler: Çeviri edinci, Teknoloji edinci, Müfredat, Çeviri eğitimi

\section{ABSTRACT}

One of the aims of academic translation education is to enable students to gain translation competence. Translation competence indicates that the translator specializes and acts consciously in the process from understanding the text to producing the target text. Therefore, it requires a number of sub-competences. This study defines all of the sub-competences forming the translation competences, i.e. language competence, text competence, cultural competence, research competence, subject and expertise competence and finally technology competence. Also, in order to make the technology competence (which is the focal point of the study), more understandable, this study examines studies on technology education in Turkish literature and translation competence models in foreign sources. After determining the borders of technology competence, courses including technology in the curriculum and the course content of the Translation Studies and Translation and Interpretation Departments of Turkey's 
13 state universities are examined. In this way, an attempt has been made to open to discussion the concept of technology competence (which is not commonly mentioned as a sub-competence in the source), to offer suggestions for students to gain or develop technology competence in academic translation education at the undergraduate level, and to associate technology competence with translation competence.

Keywords: Translation competence, technology competence, course content, curriculum, translation education 


\section{Giriş}

Teknoloji hayatımızın hemen hemen her alanında adından söz ettirmekte ve çok geniş bir alanı kaplamaktadır. Asırlardan beri insanların hayatını kolaylaşıracak farklı araç ve teknikler icat edilmektedir. Tekerleğin icadı, ateşli silahların icadı, buhar makinasının icadı, telefonun icadı, otomobilin icadı, televizyonun icadı, bilgisayarın icadı, internetin icadı gibi çeşitli yeniliklerle, insanların yaşam koşulları geliştirilmeye çalışılmışıtır. ${ }^{1}$ Böylece gelişen teknolojiyle artış gösteren bu yeniliklerin çeviri alanına da yansımaları söz konusu olmuştur. Özellikle bilgi ve iletişim teknolojilerinde yaşanan gelişmeler, çeviri dünyasında önemli değişimleri beraberinde getirmiştir. Uluslararası iletişimin yoğunluk kazanmasıyla çeviri alanlarında teknoloji kullanımı zorunluluk haline gelmiştir (Canım-Alkan, 2013:128). Çeviri sürecinde teknolojinin bu denli gerekliliği çeviri eğitiminde de sorgulanmaya başlanmıştır. Özellikle son yıllarda teknoloji konusuna çeviri eğitiminde nasıl yer verileceği konusundaki tartışmaların artı̧̧ göstermesiyle birlikte, çalışma kapsamında incelenen kaynak ve verilerden de görüleceği gibi bu konuda henüz fikir birliği sağlanmadığı anlaşılmaktadır. Çeviri piyasasının bileşenlerinden biri olan çeviri işletmeleri, çeviri eğitimi veren kurumlardan öğrencilere teknoloji kullanımını sağlamalarını beklemektedir. ${ }^{2} \mathrm{Bu}$ nedenle üniversitelerin müfredatlarını düzenlerken çeviri piyasasının güncel koşullarını dikkate alması da öngörülebilir. Ancak üniversitelerin ve piyasanın 'teknoloji edinci' kavramına bakışı birbirinden farklıdır. Üniversiteler çeviri teknolojileri üzerine genelde daha temel kullanım bilgisine ağılık verirken, çeviri işletmeleri daha çok bilgisayar destekli çeviri araçlarının ve çeviriye yardımcı yazılımların kullanım bilgisini temel almaktadır. Fakat üniversitelerde bu tür teknolojinin öğretimi ve kullanımı açısından piyasaya oranla teknik olarak kısıtlayıcı birçok faktör bulunmaktadır. Bu nedenle teknoloji kullanımına yönelik uygulamalı derslerin yoğun şekilde verilmesi üniversiteler açısından zorlayıcı olabilmektedir.

Makalede teknolojik gelişmelerin çeviri eğitiminde genel olarak nasıl işlenebileceğini tartışmadan önce öncelikle akademik çeviri eğitimin amaçlarına genel olarak dikkat çekmek gerektiği kanısındayım. Günümüzde çeviri eğitiminin ilke ve amaçları çeşitli düzeylerde tartışılmaya devam etmektedir. Ayşe Nihal Akbulut çeviri eğitimi üzerine yaptığı bir söyleşide akademik çeviri eğitiminin "öğrenciye bilgiye ulaşma yollarını göstermek, edindiği bilgiyi işlevselleştirmesini öğretmek, neyi neden yaptığı konusunda onu bilinçlendirmek, verdiği kararların arkasında durabileceği güveni kazanmasını sağlamak olarak" özetlenebileceğini ifade etmiştir (Akbulut, 2006). Sakine Eruz Çeviriden Çeviribilime adlı kitabında, çeviri eğitiminin tek bir amacı olmadığını ancak üst amacın öğrenciye dört yıllık çeviri eğitimi sürecinde basamak basamak oluşturulan bir çeviri edinci kazandırmak olduğunu vurgulamaktadır. Çeviri eğitimi öğrenciye yöntem kazandırmayı, öğrendiklerini toplumsal sınırları da dikkate alarak

1 Geçmişten günümüze teknolojik gelişmeler için bkz. (çevrimiçi), http://www.emo.org.tr/ekler/1071a1452b40720_ ek.pdf?tipi $=46 \&$ turu $=X \&$ sube $=0,(06.02 .2020)$

2 Bu bilgiye İstanbul Üniversitesi Çeviribilim Bölümü Almanca Mütercim Tercümanlık Anabilim Dalı öğrencilerinin zorunlu staj deneyimlerinin işlendiği ‘Staj Değerlendirme' dersi kapsamında ulaşılmıştır. Öğrencilerin staj yaptıkları farklı çeviri bürolarında genelde teknoloji kullanımına yönelik eksiklik dile getirilmiştir. 
sürekli kuramla ilintilendirmeyi ve öğrencinin geniş bir kültür edinci edinmesini sağlamayı amaçlamalıdır (Eruz, 2003:72). Rahman Akalın ve Mehmet Gündoğdu "Akademik Çeviri Eğitiminin Temel İlkeleri Üzerine Düşünceler: Uygulanan Ders İzlenceleri Bağlamında Hedefler ve Beklentiler" adlı çalışmasında akademik çeviri eğitiminin amacının öncelikli olarak mesleki alanda çevirmenliği öğretmek olduğunu ve bu anlamda çevirmen adaylarının edinmesi gereken en temel becerilerin başında çeviri edinci geldiğini dile getirmektedirler (Akalın ve Gündoğdu, 2010: 98). Araştırmacıların bu ifadelerinden yola çıkarak akademik çeviri eğitiminde öğrencilere çeviri edinci kazandırmanın, üzerinde uzlaşılan amaçlardan biri olduğunu söyleyebiliriz. Bu noktada konunun anlaşılırlığı için edinç kavramının ne olduğuna biraz değinmek yerinde olacaktır. Edinç, psikoloji, eğitim bilimleri ve sosyoloji gibi farklı disiplinlerde ele alınan ve bu nedenle tanımlanması zor olan bir kavramdır. Ancak edinç kavramını çeviribilim kapsamında değerlendirdiğimizde başka bir anlama bürünmektedir. Çeviribilim alanının kuruluşu 1970'li yıllara denk gelmesine rağmen edinç kavramı bu tarihten oldukça geç dönemlerde ele alınmaya başlanmıştır. Çalışma kapsamında incelenen kaynaklardaki bilgilere göre, öğrencilere çeviri edinci kazandırmayı amaçlayan çalışmalarla birlikte bu kavram yoğun şekilde gündeme gelmeye başlamıştır. Çeviri edinci, bir üst kavram olarak farklı bileşenlerle değerlendirilmektedir. Bu bileşenler ise alt edinçler olarak adlandırılmaktadır. Tüm bu alt edinçler bir araya gelerek çeviri edincini oluşturmaktadır. Çeviri edinci kavramı çalışmanın ilk bölümünde kapsamlı şekilde farklı araştırmacıların görüşleri neticesinde tanımlanmaya çalışılacaktır.

Çeviri edincini oluşturan alt edinçler ise birbiriyle etkileşim içindedir ve birbirlerini tamamlayıcı özellikler taşımaktadır. Sakine Eruz, çeviri edincinin üç temel bileşeni olduğundan söz etmekte ve bunları kültür edinci, dil edinci ve metin edinci olarak belirtmektedir (Eruz: 2008:219). Neubert ise çeviri edincini; dil, konu, metin, kültür ve aktarım edinci olmak üzere beş alt edinçten oluşan bir kavram olarak görmektedir (Neubert, 2000: 6-10). Ancak çeviribilim alanı araştırmacıları tarafından çeviri edincini oluşturan alt edinçlerin sayısında henüz bir uzlaşma yoktur. Bu nedenle çalışma sürecinde incelenen kaynakların çoğunda ele alınan dil edinci, metin edinci, kültür edinci, araştırma edinci, konu ve uzmanlık alanı edinci ikinci bölümde tanımlamalarıyla ele alınacaktır.

Tüm bu verilerden yola çıkarak teknolojinin çeviri eğitimine yansımalarını görmek ve bu çalışmada ele alınan teknoloji edinci ile neyin ifade edildiğini belirleyebilmek için üçüncü ve dördüncü bölümlerde Türkiye'de çeviribilim literatüründen ve yabancı literatürde teknoloji edincine yer veren çeviri edinci modellerinden yararlanılarak çalışmanın odak noktasını oluşturan teknoloji edinci değerlendirilip, kapsamlı bir teknoloji edinci açıklamasına varılmaya çalışılacaktır.

Çalışmanın beşinci bölümünde Türkiye'nin yedi coğrafi bölgesinde bulunan ve bünyesinde Çeviribilim veya Mütercim Tercümanlık Bölümü barındıran devlet üniversiteleri ÖSYM'nin 2019-2020 yılına ait tercih kılavuzundan tespit edilmiştir. Yapılan araştırmalar doğrultusunda her bölgeden ikişer tane devlet üniversitesinin müfredatı ve ders içerikleri incelenmeye 
özen gösterilmiştir. Bu incelemede bölümlerin hangi bölgelerde daha yoğun olduğu da göz önünde bulundurulmuştur. Marmara bölgesindeki üniversitelerde Çeviribilim veya Mütercim Tercümanlık Bölümlerinin daha fazla olması nedeniyle bu bölgeden üç üniversite; Akdeniz ve Doğu Anadolu bölgesinde yer alan devlet üniversitelerinde ilgili bölümler yaygın olarak bulunmadığından veya bölümün olup henüz öğrenci alımının gerçekleşmediğinden dolayı bu bölgelerden sadece birer tane üniversite değerlendirilecektir. Bu çalışmada özel üniversitelere göre maddi imkânların kısıtlılığı ve bu nedenle gerekli teknolojik kaynakların sınırlı olması ve devlet üniversitelerinde ilgili bölümlerin özel üniversitelerden daha fazla olması nedeniyle sadece devlet üniversiteleri incelemeye alınacaktır. Ders içeriklerine her bölümün internet sayfası üzerindeki bilgiler kapsamında ulaşılmıştır. İnternet sayfasında yer almayan ders içerikleri için ilgili bölümlere mail üzerinden ulaşılmış, ancak hepsinden dönüş alınamamıştır. Elde edilen veriler doğrultusunda Türkiye genelinde toplamda 13 devlet üniversitesinin müfredatı ve ders içerikleri incelenerek çeviri eğitiminde teknoloji edincini kazandırmaya ve geliştirmeye yönelik dersler sorgulanacaktır. Bu doğrultuda çalışmanın odağı olan ancak alanın kaynaklarında bir alt edinç olarak yaygın şekilde anılmayan teknoloji edinci kavramını tartışmaya açmak hedeflenmektedir. Konuyla bağlantılı olarak da müfredat incelemesinden sonra lisans düzeyinde akademik çeviri eğitiminde öğrencilere teknoloji edinci kazandırma ve geliştirme konusunda öneriler sunulmaya çalışılacaktır.

\section{1. Çeviri Edinci}

Edinç, birçok alanda ele alınan ve çok boyutlu yapıya sahip olan bir kavramdır. Bu nedenle farklı tanımlar getirilmiştir. Kavramın bu özelliğinden dolayı tanımlanması konusunda ortak bir karara varmak oldukça zordur. Oktay Eser'in tezinde belirtildiği edinç psikoloji, eylem ve sosyoloji kuramları çerçevesinde betimlenmiş ve edinç yerine nitelik, yeterlik, bilgi ve beceri gibi başka kavramların da kullanıldığı belirtmektedir (Eser, 2013:1). ${ }^{3}$

Çeviri öğretimine yönelik araştırmalarla birlikte, alanın araştırmacıları çeviri edinci kavramı üzerinde yoğunlaşmışlardır. Bununla birlikte günümüzde çeviri edincinin ortak şekilde karar verilmiş tek bir tanımı yoktur. Bu nedenle ele alınan aşağıdaki tanımlar, tarih sırasına göre ve çeviri edincini konu alan kaynaklardan farklı tanımlara yer verilmiştir.

Çeviri edinci, Presas'a göre çeviri için gerekli olan bildirimsel veya işlemsel bilgi türlerinin temelindeki sistem olarak tanımlanabilir ( Presas, 2000: 28). ${ }^{4}$

Profesyonel bir çevirmenin teorik eğitim ve pratik deneyimin birleşiminden geliştirdiği beceri, uzmanlık ve karar verebilme açısından çeviri edinci, Fraser tarafından bir kısa yol olarak tanımlanmaktadır (Fraser, 2000: 53).

Neubert çeviri edincinin karmaşıklık, ayrışıklık, yaklaşıklık, açık-uçluluk, yaratıcılık, durumsallık ve tarihsellik olarak yedi özellikten meydana geldiğini belirtmektedir (Neubert,

3 Edinç kavramının bu özelliğiyle ilgili ayrıntılı bilgi için bkz. Eser, O.(2013). Çeviri Eğitiminde Edinç Kavramının Değerlendirilmesi, İstanbul Üniversitesi Sosyal Bilimler Enstitüsü, Doktora Tezi, s. 1-3.

4 Aksi belirtilmedikçe bu çalışmada yer alan çeviriler tarafıma aittir. 
2000: 3-5). Araştırmacı, çeviri edincini özelliklerini sıraladıktan sonra onu oluşturan alt edinçlerini de saptamıştır. Neubert'e göre çeviri edinci dil, metin, konu, kültür ve aktarım edincinden oluşmaktadır (Neubert, 2000: 6-10).

Yukarıdaki tanımlardan farklı olarak Risku, çeviri edincini kültürlerarası iletişim durumlarını düzenleyebilmek için gelişmiş bir yetenek olarak açıklamaktadır (akt. Meyer, 2009: 22).

Çevirmenin çeviri edincini iki temel beceri üzerine temellendiren Amman, bu iki temel becerinin de kültür edinci ve metin edinci olduğunu savunmaktadır (Amman, 2008: 67).

Edinç kavramının dilbilim, yabancı dil öğretimi ve çeviribilim alanlarında kullanıldığını belirten Ergun, bu kavramın ilgili disiplinlere göre farklı anlambirimcikler içerdiğini savunmaktadır. Örneğin dilbilimde edinç gücül olarak sahip olduğumuz bir donanımı belirtir. Yabancı dil öğretiminde edinç, dilbilimdeki gibi durağan bir donanım değil, somut ürünü olan bir etkinliği anlatır. Çeviribilimde ise edinç hem bilgi edinimini hem de bu bilgilerin başarılı çeviriler üretmek için kullanımını içerir (Ergun'dan aktaran Işık Akdă̆, 2015: 14).

Akbulut'a göre çeviri edinci, öğrencinin dil becerisi ve dil eğitiminde verilenlerden farklı, diğer gerekli becerilerin bireşimini yaparak bunlara işlerlik kazandırabilmesini sağlayan bir üst bilinçtir (Akbulut, 2004: 34).

Çeviri eğitiminde amacın çeviri edincini geliştirmek olduğunu vurgulayan Yazıcı' ya göre çeviri edinci, çevirmenin çeviri öncesinden başlayarak yaptığ anlamina gelmektedir (Yazıc1, 2005:175).

Çeviri edincini, çevirmenin çeviri çözümleri üretirken başvuracağı dilsel, ama aynı zamanda biçemsel ve yazınsal olabilen kaynaklar olarak niteleyen Toury, ayrıca bu edincin ancak bilinçli bir eğitim ve deneyimle kazanılabileceğine işaret eder ve asıl çevirmenliğe sadece bu şekilde geçilebileceğini öne sürmektedir ( Toury’den aktaran Berk, 2005:119).

Çeviri edincini öğrenilebilir ve edinilebilir bir edinçler bütünü olarak tanımlayan Eruz, aynı zamanda çeviri edincini kültür edinci, dil edinci, metin edinci bileşenlerine ayırmaktadır ve çevirmenin bu bilgileri güncelleştirebilmesi için uzmanlık bilgisi (çeviribilimsel bilgi ve uzmanlık alanında çeviri odaklı bilgi) ve ilgili araştırma yöntemleriyle harmanlaması gerektiğini ifade etmektedir ( Eruz, 2008:219).

Yukarıdaki tanımlardan yola çıkarak araştırmacıların çeviri edinci kavramı için birbirinden bazı noktalarda ayrılan tanımlar kullandığı görülmektedir. Tüm bu tanımlardan hareketle çeviri edinci kavramı üzerine genel bir değerlendirme yapabilmek mümkündür. Genel anlamda çeviri edinci, öncelikle etkin bir anadil ve yabancı dil becerilerine dayanır. Çevirmen tarafından çevrilecek metne bilinçli bir erişimi sağlar. Çevirmenin, çeviri ile ilgili metinsel analiz yapabilme, çeviri stratejilerini bilme, uygun çeviri stratejilerini seçme ve bunları doğru kullanma konusunda uzmanlaşmasına işaret eder ve bu uzmanlaşmanın da eğitim yoluyla sağlanabileceği söylenebilir. Çeviri edinci ayrıca çeviri sürecinde gerekli olan çeviri stratejilerinin belirlenmesini ve uygulamasını içerir. Metin türüne ve dillere bağlı olarak, çevirmenin sahip olduğu kültürel bilgi de bu sürece etki etmektedir. Çeviri edinci ağırlıklı olarak onu oluşturan "alt edinçler” ya 
da "yardımcı edinçler" ile birlikte değerlendirilmiştir. Dolayısıyla çeviri edinci kaynak dil ve erek dil edinçlerinin yanı sıra bir takım alt edinçler gerektirir. Çalışmanın bütünlüğü açısından bir sonraki bölümde çeviri edincini oluşturan bu alt edinçler ayrıntılarıyla aktarılacaktır.

\section{2. Çeviri Edincini Oluşturan Alt Edinçler}

$\mathrm{Bu}$ çalışma süresince yaptığım incelemeler doğrultusunda, çeviri edincini oluşturan bütün alt edinçler için araştırmacılar tarafından ortak karar verilen net bir sayının olmadığını söylemek olanaklıdır. Taranan kaynaklardaki araştırmacıların ele aldığı aynı alt edinçlerin açıklamalarına yer vermek, bu çalışmanın sınırlarını belirleme açısından daha doğru olacaktır. Bu bölümde dil edinci, metin edinci, kültür edinci, araştırma edinci, konu ve uzmanlık alanı edinci ve asıl olarak çalışmamın odak noktasını oluşturan teknoloji edinci kavramları veya alt edinçleri sırasıyla tanımlanacaktır. Ayrıca incelenen kaynaklarda araştırmacıların alt edinçleri tanımlarken ağırlıklı olarak kullandıkları sıralama benim çalışmamda da temel alınmıştır.

Dil edinci, bir çevirmenin en az iki dile hâkim olmasına işaret etmektedir. Dil edinci söz konusu dillere ait türlü dilsel bilgiyi; dilbilgisel kuralları, sözlükbilgisel kullanımları, deyimleri, dillere özgü görsel ve yazınsal özellikleri anlayabilmeyi ve doğru bir şekilde herhangi bir şeyi ifade edebilmeyi gerektirmektedir. Çoban, dil edinciyle ilgili şu sözleri dile getirmektedir:

"Birinci dil edinci çeviri eğitiminin temel yapıtaşlarından biridir ve çeviri eğitimi ders programlarında bu edinç türünün edinilmesine önem verilmelidir. Çeviri edincinin diğer bir kolunu oluşturan unsur da çevirmenlerin ikinci bir dile yani yabancı dile hâkim olmalarıdır." (Çoban: 2013:100)

Çoban'ın bu söyleminden yola çıkarak, dil edincinin temel bileşenlerinden ilkinin anadil edinci, ikincisinin yabancı dil edinci olduğunu belirtebiliriz. Ancak çeviri işi yalnızca sözcüklerin karşılığını hedef dile aktarmak değildir. Bu nedenle anadil edinci ve yabancı dil edinci tek başına işlevsel çeviri üretmeye yeterli değildir. Dolayısıyla dil edinci, çeviri için tek başına yeterli değil, ancak sahip olunması gereken ölçüttür denilebilir. Çevirmenin söz konusu dillerle ilgili bütün bilgilere sahip olması elbette mümkün olmayabilir. Ancak çevirmen yeri geldiğinde eksik olduğu dilsel bilgisini tamamlamalıdır. Ayrıca gelişen ve değişen dünyamızda diller de devingen bir özellik göstermektedir. Bu nedenle çevirmenlere düşen bir başka görev hâkim oldukları dillerin değişimini ve gelişimini takip etmektir.

Metin edinci temel olarak bir çevirmenin metni anlaması ve yeniden bir metin üretmesi süreçlerini kapsar. Çevirmenler, ilgili metnin uzmanları olarak metinleri anlamak ve amaca uygun şekilde bir metin üretmek durumundadır. Bunun için çevirmenlerin metin türü geleneklerine dair bilgiye sahip olması çeviri sürecinde yararlı olacaktır. Bu noktada Göktürk'ün sözleri bu düşünceyi destekleyici niteliktedir:

"Metin türü gelenekleriyle ilgili bu konularda ayrıntılı bilgi, değişik metinlere uygulanacak doğru çeviri yönteminin saptanmasında da sonsuz yarar sağlar. Metin türünün geleneği her yönüyle göz önünde tutulabilirse, hangi metinlerin iletişimsel yöntemle, iletinin aktarılmasına 
ağırlık verilerek çevrilebileceği, buna karşılık hangi metinlerin dilsel biçimine ağırlık verilmesi gerektiği daha kolay kararlaştırılabilecektir. Metnin türüne göre, kaynak dilde yansıttığ 1 geleneklerin, hangilerinin çeviri diline aktarılmaya değer, hangilerinin aktarılması gereksiz olduğu buna göre belirlenir." (Göktürk, 2013: 36)

Çevirmenin bir metne çeviri amaçlı yaklaşması gerekmektedir. Metne bir bütün olarak bakar, metni alımlar ve anlamlandırıp yeni bir dilde yazar. Yani kaynak metni işlevsel bir şekilde çözümleyerek erek dilde yeniden bir metin oluşturur.

Çevirmenler, çeviri sürecinde kaynak ve hedef kültür arasında iletişim kurabilmek için kültürlerarası bilgiye ihtiyaç duyarlar. Kültürlerarası bu bilgi kültür edincini beraberinde getirir.

"Kültür edinci kişinin kendi üyesi olduğu kültürden ve içinde bulunduğu durumdan soyutlama, yabancı kültürü -bütün özelliklerini dikkate alarak ve kendi kültürü ile kıyaslayarak-izleme, bunları yaparken de gözlemlerini ve oluşturduğu varsayımları belli bir (iletişimsel) durumda hedefi ve kültürü gözeterek uygulama becerisi $[\ldots]$ "

olarak tanımlanmaktadır (Amman, 2008: 73). Kültür edinci hem kaynak dil hem de erek dilde çevirmenin sahip olması gereken bir edinçtir. Çeviri sadece dilsel bir aktarım olarak görülmez, aynı zamanda kültürel bir aktarımı da içermektedir. Çalışma kapsamında incelenen kaynaklardaki kimi araştırmacılar, çevirmenin diğer bir kültüre hâkim olması için önce kendi dilinin kültürüne hâkim olması gerektiğini savunmaktadır. Dolayısıyla çevirmen farklı kültürler arasında profesyonel olarak hareket edebilmeli yani çift kültüre sahip olmalıdır.

Araştırma edinci, çevirmenin çeviri sürecinde metin üzerinde yaptığı her türlü araştırmayı kapsar. Çevirmen çeviriye başlarken çeviri amaçlı metin çözümlemesi yapmaktadır. Herhangi bir metinde yer alan konu bilgisi veya alan bilgisi çevirmende eksik olabilir. Çevirmenlerin hukuk, iktisat, tıp, mühendislik, bilişim vb. bütün uzmanlık alanlarının bilgisine sahip olması mümkün değildir. Bu durumda çevirmen eksik olduğu bilgiyi tespit etmeli ve gerekli araştırma yöntemlerini uygulayarak onu gidermeye çalışmalıdır.

"Çevirmen, devingen davranarak erek metni kuşatan oluşum koşulları çerçevesinde yeni kararlar alan ve aldığg kararların sağlamasını yapan uzman kişidir. Çeviri edincine sahip çevirmen bu tür bir üst bakış açısını kazanmış, her çeviri işinde işlevsel davranabilmek için gerekli araştırma kaynaklarına başvurarak en kısa zaman kaybını göze alarak doğru kararları alabilen bir uzman konumunda karşımıza çıkar.” (Eruz, 2008: 52)

Eruz'un söyleminden de anlaşılacağı üzere, çeviri edincine sahip bir çevirmen gerekli araştırma kaynaklarına başvuran, araştırma edincine sahip bir uzman konumundadır. Ansiklopediler, alan kitapları, sözlükler, koşut metinler gibi geleneksel kaynakların yanı sıra elektronik araçlar da (bilgisayar, çevrimiçi sözlükler, arama motorları vb.) çevirmenler tarafindan kullanılabilir.

Uzmanlık alanı metinlerinin çevirisinde, çevirmenin metni tam olarak anlayabilmesi için sahip olması gereken uzmanlık alanı bilgisi konu ve uzmanlık alanı edincine işaret etmektedir. Uzmanlık metinleri kültürel açıdan donanım ve uzmanlık gerektiren, geniş alan 
bilgisi barındıran metinlerdir. Ana dilde ve yabancı dilde uzmanlık metinlerini karşılaştırmak uzmanlık edinci kazanmaya katkı sağlayacaktır. Ayrıca uzmanlık metinleriyle çalışmak çeviribilim araştırmacıları tarafından çeviri edincini destekleyen çok önemli çalışmalar olarak görülmektedir. Budin'e göre uzmanlık alanı çevirisi olmadan uluslararası, kültürlerarası, diller arası düzeyde bilgi yönetimini hayal etmek bile zordur (akt. Meyer, 2009: 76). Dil ve iletişim engellerini aşmak için kültürlerarası uzmanlık alanı iletişimini sağlayacak olan uzmanlık çevirisi gereklidir. Çevirmenlerin bu bilgi akışını sağlaması için uzmanlık bilgisine ihtiyacı vardır. Bu da çevirmenin sürekli olarak yeni bir uzmanlık alanı bilgisi edindiği ve bu uzmanlık bilgisini koruduğu anlamına gelmektedir.

Ülkemizde son y1llarda özellikle teknolojinin gelişmesi ve çevirinin de bu gelişime ayak uydurma zorunluluğu ile teknoloji edinci kavramı gündeme gelmeye başlamıştır. En temel anlamda bilgisayarı kullanma bilgisi, bilgisayarla yazma ve araştırma yapma, terminoloji geliştirme, terminoloji oluşturmak için veri bankası kurulumu, farklı multi medya araçları bilgisi, dil, bilgi ve iletişim teknolojileri alanındaki gelişmeleri izleme, çeviri programları, çeviriye yardımcı programlar, internet kullanımı ve elektronik ortamdaki yararlanılabilecek bu türden bütün kaynaklar teknoloji edinci konusu altında ele alınabilmektedir. Teknoloji edinci, çevirmenin çeviri sürecinde kullandığı her türlü elektronik araçların bilgisine ve kullanımına işaret etmektedir. Çalışmamın odak noktasını oluşturan teknoloji edinci gelecek bölümde ayrıntılı ele alınacaktır.

\section{Türkiye'de Çeviribilim Literatüründe Teknoloji Edinci}

Teknolojik gelişmeler ve bilgisayar kullanımı hemen hemen her alanı etkilediği gibi Çeviribilim Bölümlerini de etkilemiştir. Bilgisayar ülkemizde ilk kez 1960'lı yıllarda kullanılmaya başlanmıştır. Bu buluşun eğitime yansımaları ise 70'li yılları bulmuştur. Ülkemizde Çeviribilim Bölümlerinin kuruluşu da 80'li yıllara denk gelmektedir. Fakat o y1llarda bu bölümlerin müfredatında teknolojiyi konu alan derslere yaygın şekilde yer verilmemiştir. Teknoloji alanında hızlı gelişmeler olmasına rağmen çeviri eğitiminde teknoloji kullanımı oldukça sınırlı kalmıştır (bkz. Şahin, 2013:5). Bu durumu Şahin şu sözleriyle desteklemektedir:

\footnotetext{
"Çeviri eğitiminde teknoloji kullanımının en çok hissedildiği alan olarak sözlü çeviri eğitimi öne çıkmaktadır. 1990'lı yılların sonuna kadar çoğu çevirmen okulunda kullanılan en yüksek teknoloji ses kasetleri ve tepegözler iken bugün daha farklı teknolojiler yaygın olarak kullanılmaktadır. Yazılı çeviri eğitiminde teknoloji kullanımının ise, bugün çoğu kuruluşta, en fazla PowerPoint yansılarından ibaret olduğunu söylemek yanlış olmaz. Bununla birlikte gün geçtikçe İnternet’teki çeviri ediminde kullanılabilecek kaynaklar daha fazla kişi tarafından keşfedilmekte ve çeviriye yönelik yazılım ve araçların kullanımı gittikçe artmaktadır." (Şahin, 2013:5)
}

Şahin'in yukarıdaki söylemi üzerinden altı sene geçtiğini düşünerek, günümüzde çeviri eğitiminde teknoloji kullanımına daha fazla yer verildiğini söylemek mümkündür. Bu doğrultuda Çeviribilim Bölümlerinin müfredatlarında, teknoloji kullanımına yönelik derslerin de yaygınlaşmaya başladığı görülmektedir. Gelecek bölümlerde de göreceğimiz üzere, çeviri sürecine yönelik yazılım ve 
araçlarla ilgili derslerin bu bölümlerde artık zorunlu ve seçmeli olarak yer aldığını bulgulayabiliriz. Dolayısıyla zaman içinde teknoloji kullanımının çeviri sürecinde adından daha fazla söz ettirmeye başladığını ve bu durumun ilerleyen süreçte daha da artacağını söylemek yerinde olacaktır.

Daha önce bahsettiğimiz gibi çeviri bir üst edinç ise, teknoloji edinci de onun oluşumuna katkı sağlayan bir alt edinç veya yardımcı edinç olarak yerini almaktadır. Türkiye'de çeviribilim alanındaki araştırmacıların teknoloji kullanımına ve teknoloji edincine yönelik ele aldığ çalışmalara göz attığımızda ‘teknoloji edinci' kavramının hangi sınırlarda ele alındığını görmek mümkün olacaktır. Bu amaçla incelenecek kaynakların sınırlarını belirleyebilmek için, bu çalışmada üzerinde durulan konuyla ilgili olarak Türkiye'de Yükseköğretim Tez Merkezi'nde 2008-2018 yılları arasında yayımlanan tezler, internet üzerinde dergipark.org.tr, www.academia. edu ve www.idealonline.com.tr (Uluslararası Dil, Edebiyat Eğitimi Dergisi) sitelerinde açık erişim olarak yayımlanmış makale ve kitaplar kronolojik bir sıra ile aktarılmaktadır.

"Çeviribilim Bölümlerinde Verilen Derslerin, Özellikle Bilgi Teknolojileri Derslerinin, Çeviri Edinci Kazanılmasına Katkısı” (2004) isimli makalesinde Yazar, teknoloji edinci konusunu ele alırken özellikle bilgisayar destekli çeviri (CAT) programları üzerinde durmuştur. Bilgisayar destekli çeviri yazılımlarının çeviri belleği, terminoloji yönetimi ve çeviride proje yönetimi bileşenlerinden oluştuğuna dikkat çekmiş ve bu tür yazılımların çevirmenlere sağladığı kolaylıklardan bahsetmiştir.

Türkiye'de çeviri edinci üzerine çalışmalar yapan Yazıcı, günümüz koşulları altında çeviri edincinin yedi tane alt edinçten oluştuğuna dikkat çekmiştir. Bu yedi tane alt edinci önem sırasına göre sıralamış ve beşinci sırada 'elektronik araçlarla ilgili bilgi' ye yer vermiştir. Bu alt edinci de, çeviri belleklerini kullanabilme ve veri tabanı oluşturabilme gibi becerileri de kapsayan elektronik kaynakları verimli kullanabilme bilgisi (Yazıc1, 2007:139) olarak tanımlamıştır. Yazıcı'nın burada ele aldığı alt edincin birebir teknoloji edinci olarak adlandırmadığı görülmektedir. Fakat çeviride teknoloji bilgisine ve kullanımına yönelik bir edince vurgu yaptığını söylemek olanaklıdır.

Türkiye'de Çeviri Bürolarında Web Sitesi Yerelleştirmeleri ve Bu Süreçte Bilgi Teknolojilerinin Kullanımı (2008) başlıklı yüksek lisans tezi, yerelleştirme ve çeviride bilgi teknolojileri konusunu ele alan bir çalışmadır. Canım Alkan'ın bu çalışmasının ilk bölümünde çeviri ve bilgi teknolojileri ilişkisini ayrıntılı olarak açıklanmış ve çeviribilim literatüründe yerelleştirme sürecinin, bu süreçte bilgi teknolojilerinin kullanımının, sürecin aktörlerinin ve bu aktörlerin görev kapsamlarının nasıl betimlendiğini aktarmaya çalışmıştır. Ayrıca Türkiye'de web sitesi yerelleştirme sürecinin, çeviribilim literatüründe tanımlanan biçimiyle işleyip işlemediğini çeviri bürolarıyla yapılan bir anket çalışmasının verileri ışığında tartışmıştır.

Bilişim teknolojilerinin çeviri alanındaki etkilerini Bakır, Yazılımda Yerelleştirme ve Çeviri (2012) başlıklı yüksek lisans tezinde incelemiştir. Bakır, çeviribilim ve yerelleştirme konusunu detaylandırmış ve uzmanlık metinleri üzerinde yapılmış çalışmalarla örneklendirilmiştir. Ayrıca bu çalışmada çeviribilim ve yerelleştirme çalışmalarının benzeştiği ve ayrıldığı noktaları incelemiştir. 
Çalışmamızın çerçevesi doğrultusunda teknoloji edincine veya kullanımına dair doğrudan veri sunmayan ancak gelişen teknolojinin çevirmenler üzerindeki etkilerini ele alan bir başka çalışma ise, "Teknolojik Gelişmelerin Çevirmen ve Çeviri Mesleği Açısından Olumlu ve Olumsuz Etkileri: Çeviri Alanında Yeni Yaklaşımlar” (2012) adlı makaledir. Ersoy ve Balkul'un yazdığı bu makalede, olumlu ve olumsuz yönleriyle teknolojik gelişmelerin çevirmen haklarına, çevirmenler arası ilişkilere, çevirmen-işveren ilişkilerine, akademik çeviri eğitimine, çevirmenin yaşam tarzına ve çevirmenin mesleki gelirine ne tür etkilerde bulunduğuyla ilgili veriler sunulmuştur.

Teknoloji eğitimiyle ilgili olarak "Lisans Düzeyinde Çeviri Eğitiminde Teknoloji Eğitiminin Yeri” (2013) makalesinde Canım Alkan, öncelikle çeviribilim literatüründe teknoloji eğitimini incelemiş ve İstanbul Üniversitesi İngilizce Mütercim-Tercümanlık bölümünde okutulan Çeviride Bilgi Teknolojileri dersinden yola çıkarak çeviri eğitimine teknoloji eğitiminin nasıl dâhil edilebileceğini tartışmıştır.

Çeviri Eğitiminde Çeviri Edinci Geliştirme Alışkanlıkları (2013) adlı doktora tezinde, Haldan diğer çalışmalardan farklı olarak teknoloji edinci kavramına ve bu kavramın tanımına ayrıca yer vermiştir. Bu edincin son yıllarda toplumsal, ekonomik ve teknolojik değişim süreçleri açısından çevirmenlerin rekabet edebilirlikleri için vazgeçilmez bir koşul olarak görüldüğüne dikkat çekmiştir. Teknoloji edincini bilgisayarla yazma ve araştırma yapmak amaçlı kullanım bilgisi, dil tanıma, terminoloji geliştirme, aynı zamanda terminoloji oluşturmak için veri bankası kurulumu, kullanımı ve bakımı gibi çok farklı multi medya araçları bilgisi, dil, bilgi ve iletişim teknolojileri alanındaki gelişmeler olarak tanımlamıştır.

Bir diğer çalışma, Yerelleştirme ve Çeviri: Çeviribilimde ve Çeviri Eğitiminde Yerelleştirmenin Konumu (2013) başlıklı yüksek lisans tezinde Öztürk, yerelleştirme süreçlerinde kullanılan çeviri teknolojilerine değinmiş ve bu yazılımların nasıl bir çalışma sistemine sahip olduklarının yanında çevirmenlerin bu araçlardan nasıl faydalanabileceklerini ayrıntılı şekilde ele almıştır.

Balkul, Türkiye'de Akademik Çeviri Eğitiminde Çeviri Teknolojilerinin Yerinin Sorgulanması (2015) başlıklı doktora tezinde çeviride kullanılan teknolojiler, makine çevirisi programları ve bilgisayar destekli çeviri başlıkları altında araştırmalarını gerçekleştirmiştir. Bilgisayar destekli çeviri programları üst başlığı altında da çeviri bellekleri, terminoloji yönetim sistemleri, çeviri yönetim sistemleri, masaüstü yayıncılık araçları, yerelleştirme araçları, çevrimdışı ve çevrimiçi çalışan sözlükleri detaylandırmıştır.

Çeviride teknoloji kullanımını değerlendiren bir başka çalışma, Kırıkkale Üniversitesi İngilizce Mütercim-Tercümanlık Anabilim Dalı Öğrencilerinin Çeviri Teknolojilerine Yönelik Tutumlarının İncelenmesi (2015) adlı yüksek lisans tezidir. Çetin tarafından ele alınan bu tezde çeviri araçlarının tarihine genel bir bakış, çeviri teknolojilerine ilişkin temel kavramlar, makine çevirisi, bilgisayar destekli çeviri, çeviri bellekleri, metin eşleştirme (hizalama) araçları, terminoloji yönetimi araçları konuları üzerinde durulmuştur.

Uluslararası Karşılaştırmalı Edebiyat Bilimi Kongresinde kapsamında Aslan, Çeviri Teknolojilerinin Çevirmenin Sınırlarını Belirlemedeki Rolü (2015) adlı bir çalışma ele almıştır. 
Çalışmasında çeviri alanında kullanılan teknolojilerin çevirmenlerin sınırlarını belirlemedeki rolü üzerinde durabilmek için öncelikle çeviri teknolojilerinin önemine değinmiş ve bu teknolojileri kullanmanın çevirmenlere ne gibi kolaylıklar sağladığı ele almıştır. Bu amaçla çeviri teknolojilerinin tarihinden bahsedilerek geçmişten günümüze kadar kullanılan çeviri teknolojileri incelenerek çalışma detaylandırılmıştır. Ayrıca çevirmenin bu teknolojilerle neler yapabileceği ve çeviriye ne gibi katkılar sunabileceği üzerinde durulmuştur.

Arslan, Geçmişten Günümüze Çeviri Teknolojileri (2016) adlı bir başka çalışması kapsamında bilgisayar ve İnternet'in hayatımıza girmesiyle birlikte çeviri alanında ne tür değişiklikler olduğunu, bugün gelinen noktaya varana kadar hangi aşamalardan geçildiğini ve gelecekte ne tür teknolojilerin bu alanda kullanılabileceğini ortaya koymaya çalışmıştır.

Bilgisayar Destekli Çeviri Sürecinde Çevirmenin Görevi (2019) adlı makalede Tok, bilgisayar destekli çeviri sürecinde teknolojiye paralel olarak çevirmenin üstlenebileceği rol ve statüyü incelemeye çalışmıştır. Bu doğrultuda öncelikle çeviri teknolojilerine ve otomatik çeviri sürecine değinilmiş ve çevirmenin çeviri teknolojilerinin gelişiminden önceki rol ve işlevi ele alınmıştır. Daha sonra çeviri teknolojilerinin bu konuda yol açtığg bazı değişikliklere değinilerek bu kapsamda çevirmenin üstlenebileceği görev ve işlevler incelenmiştir.

Yukarıda gerçekleştirilen çalışmalardan yola çıkarak ülkemizde teknoloji edinci kavramının henüz tam olarak yerleşmediğini ancak çeviri eğitiminde teknoloji kullanımının son yıllarda üzerinde durulan bir konu olarak değerlendirilmeye başladığını görebiliriz. Sadece Yazıcı'nın “elektronik araçlarla ilgili bilgi” ve Haldan' ın "teknoloji alt edinci” kavramlarını ayrı olarak ele almaları, ülkemizde teknoloji edinci kavramın sınırlı kullanımına işaret etmektedir. Diğer araştırmacılar ise çeviri eğitiminde ve çeviri sürecinde teknoloji kullanımına yönelik çeşitli çalışmalar yapmış, bu anlamda çeviri eğitimine teknolojiyi dâhil etmeye katkıda bulunmuşlardır. $\mathrm{Bu}$ çalışmalara baktığımızda, araştırmacıların ağırlıklı olarak çeviriye yardımcı yazılımlar üzerinde durduğunu da belirtebiliriz. Türkiye'de 2008 ve 2019 yılları arasında teknoloji edincine ve kullanımına yönelik yapılan çalışmalarda özellikle 2013 yılında yoğunluk yaşandığını gözlemlemek de mümkündür.

\section{Yabancı Literatürde Teknoloji Edincine Yer Veren Çeviri Edinci Modelleri}

Çalışmanın bu bölümünde ise yabancı literatürde teknoloji edinci kavramına yer veren ve bu kavramı tanımlayan çeviri edinci modelleri incelenecektir. Bu amaçla yabancı kaynaklarda öncelikle ele alabileceğimiz $\mathrm{PACTE}^{5}$ grubunun oluşturduğu çeviri edinci modelidir. Çünkü bu model, diğer modeller için fikir verici niteliktedir. PACTE grubunun modeli altı tane alt edinçten oluşan bir çeviri edinci modelidir. Modelde yer alan araçsal alt edinç (instrumentelle Subkompetenz) ağırlıklı olarak kaynakların kullanımıyla ilgili bilgiyi işaret etmektedir. Bir yandan kitaplar, sözlükler, paralel metinler ve elektronik korpus gibi dokümantasyon kaynaklarını içermektedir. Öte yandan çeviriye uygulanan bilgi ve iletişim teknolojilerinin kullanım bilgisi

5 Process of Acquisition of Translation Competence and Evaluation 
yer almaktadır (PACTE, 2003). Dolayısıyla PACTE grubu, çeviri sürecinde teknoloji kullanımını bir alt edinç olarak değerlendirmiştir. Ayrıca çalışma kapsamında araştırılan bazı kaynaklarda PACTE grubunun adlandırmasından farklı olarak araçsal alt edinç kavramının teknoloji edinci adıyla yer aldığı görülmektedir.

EMT grubu ise çeviri edincini belli koşullar altında, belli bir görevi yerine getirebilmek için gerekli yetenek, bilgi, davranış ve teknik bilgi birleşimi olarak tanımlamış ve ele aldığı çeviri edinci modelinde altı tane alt edinçten bahsetmektedir. Alt edinçlerden biri olan teknoloji edinci, çeviride bilgi teknolojilerini etkin bir şekilde kullanabilmeyi içermektedir. EMT grubu teknoloji edincini düzeltme, çeviri, terminoloji, düzen, doküman araştırmalarında yardımcı olacak bir yazılım yelpazesini etkin bir şekilde kullanma bilgisi olarak tanımlamıştır (EMT, 2009:7).

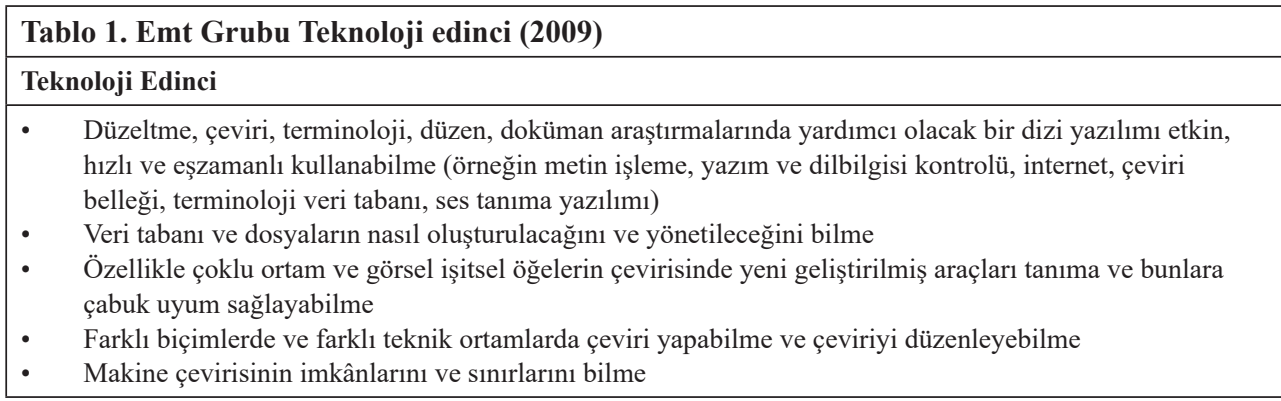

“Translationkompetenz Woher kommt sie und was ist das?” (2014) adlı çalışmada Hansen, dört tane alt bileşenden oluşan dinamik bir çeviri edinci modelini ele almıştır. Modelini oluşturan bileşenlerden biri de çeviri teknolojileridir. Onun tanımına göre çeviri teknolojileri elektronik sözlükler, internet, çeviri belleği sistemleri ve makine çevirisi gibi CAT araçlarını içermektedir.

Göpferich'in oluşturduğu çeviri edinci modeli, altı tane alt edince ayrılmaktadır. Modeldeki sonuncu alt edinç olan araçlar ve araştırma edinci, sözlükler (elektronik veya kâğıt tabanlı), ansiklopediler, metin işleme programları, çeviri belleği sistemleri, terminoloji yönetim sistemleri, internet arama motorları, korpuslar gibi çeviriye özgü geleneksel ve elektronik araçlarla ilgili bilgi ve becerileri kapsar (Krüger, R \& Serrano Piqueras, J. 2015: 12). Bu bilgilerden yola çıkarak Göpferich'in çeviri edinci modelinde teknoloji kullanımına oldukça detaylı şekilde yer verildiğini söylemek mümkündür.

Mevcut çeviri edinci modellerini yeniden yapılandıran (özellikle PACTE, EMT, Kelly’nin modelleri) Ramos, beş tane alt edinçten oluşan bir model geliştirmiştir. Bu modelde teknoloji kullanımına dikkat çekmiş ve araçsal alt edinç kavramına yer vermiştir. Araçsal alt edinç uzmanlık metinlerinin bilgisi, bilgi ve terminoloji yönetimi, paralel metinleri kullanabilme yetisi, çeviride bilgi teknolojilerini kapsamaktadır (akt. Kościałkowska-Okońska, 2016: 40).

Çalışmanın bu bölümünde yabancı kaynaklardaki çeviri edinci modellerinde yer alan teknoloji edinci tanımlarından bahsettik. Bu modellerde araçsal alt edinç ve teknoloji alt edinci gibi farklı kavramlarının kullanıldığını gözlemledik. Araştırmacıların tanımlarından teknoloji 
edinci kavramının tanımında, Türkiye'deki araştırmacılara göre kendi içlerinde benzerliğin daha fazla olduğunu söyleyebiliriz. Ayrıca teknoloji edinci bazı modellerde araştırma edinci ile birlikte değerlendirilmiştir. Ancak Türkiye'de yapılan araştırmalarla kıyaslanırsa, yabancı kaynaklarda teknoloji edincini ayrı bir alt edinç olarak değerlendirildiği söylemek mümkündür.

Son iki bölümde yapılan tanım ve çalışmalardan hareketle en dikkat çeken noktalardan biri, bazı araştırmacıların teknoloji edinci kavramını oldukça sınırlı tutmuş olmasıdır. Kimi araştırmacılar bu kavrama karşılık olarak genellikle bilgisayar destekli çeviri programlarını ön plana çıkarırken, kimisi de sadece bilgisayar vb. teknolojik araçların kullanımına odaklanmışlardır. Ancak bir kısım araştırmacı da çeviri programlarına ek olarak diğer bütün yardımcı programları, bilgisayar ve teknoloji kullanımını, dahası bütün teknolojik işlem gerektiren süreçleri teknoloji edincine dâhil ederek tanımlarını genişletmişlerdir. Ancak benim bu çalışmada ele aldığım ve daha sonra müfredat analizinde de tespit etmeye çalışacağım teknoloji edinci kavramı oldukça geniş sınırlarla kullanılmaktadır. Bir başka deyişle, yukarıda bahsi geçen araştırmacıların ele aldıkları bütün tanımları kapsayan ve geniş anlamda kullanılan bir teknoloji edinci tanımı bu çalışmanın devamında temel alınmaktadır. Dolayısıyla teknoloji edinci bir çevirmenin çeviri öncesinde, sürecinde ve sonrasında elektronik araçlarla girdiği her türlü etkileşimi işaret etmektedir. Çevirmen bu noktada çevrimiçi sözlükleri kullanma, koşut metin aramaları, terminoloji yönetimi, araştırma yöntemleri, çeviri bellekleri oluşturma ve kullanma, internet kullanabilme bilgisine sahip olmalıdır. Çevirmen bütün bilgisayar destekli araçların bilgisine sahip olmasa da benzer türde işleyen araçlarla ilgili bilgi donanımını çeviri sürecinde kullanabilmelidir. Çevirmenin sahip olduğu bütün elektronik araçların bilgisi teknoloji edincinin göstergesidir. Veri tabanı ve dosyaları yönetebilmeyi bilmelidir. Çeviri sürecinde işini kolaylaştıracak yazılımların bilgisine sahip olmalıdır, eğer bu bilgiye sahip değilse öğrenmeye açık olmalıdır. Çevirmen ayrıca çeviriye yardımcı teknolojik araçları (ses kayıt cihazı, kulaklık, tablet vb.) kullanabilmeli, bu araçlarda çeviri sürecini etkileyen bütün detayların bilgisine sahip olmalıdır. Teknoloji dinamik bir yapıda olduğu için çevirmen, teknolojik gelişmeleri takip etmeli ve kendini bu konuda güncellemelidir. En önemlisi de eksik bilgilerini kapatmaya yani öğrenmeye açık olmalıdır.

Son olarak araştırmacıların farklı kavramlar kullanarak teknoloji edincini kapsayan açıklamalarda bulunduğu söylemek mümkündür. Çeviribilim araştırmacıları ve araştırma grupları tarafından ileri sürülen araçsal edinç, teknoloji edinci ve elektronik araç bilgisi gibi başlıklar bu makale kapsamında tek bir kavramla, teknoloji edinci kavramıyla değerlendirilmiştir. $\mathrm{Bu}$ bilgilere ek olarak, incelenen kaynaklar doğrultusunda bazı araştırmacıların teknoloji kullanımına araştırma edinci gibi bir başka alt edinç altında yer verdiği de görülebilmektedir. Bu noktada yapılan bütün araştırmalar doğrultusunda, teknoloji edinci kavramı üzerine çeviribilim alanında henüz bir uzlaşmaya varılmadığı ve bütün araştırmacılar tarafından ayrı bir alt edinç olarak ele alınmadığı da söylenebilir. 


\section{5. Çeviri Eğitiminde Teknoloji Edincini Geliştirmeye Yönelik Dersler}

Bu bölümde teknoloji edincinin bir önceki bölümde ele alınan geniş anlamdaki tanımı temel alınarak, çeviri eğitiminde teknoloji edinci tanımının sınırlarına dâhil olan dersler incelenmiştir. Bu amaçla Türkiye'deki Çeviribilim veya Mütercim Tercümanlık Bölümü barındıran devlet üniversiteleri araştırılmıştır. ÖSYM tercih kılavuzundan elde edilen verilere göre, 2019-2020 akademik yılında ülkemizde lisans düzeyinde aktif olarak çeviri eğitimi veren 27 devlet üniversitesinin farklı dillerde mevcut 43 bölümünün ve 22 vakıf üniversitesinin farklı dillerde mevcut 30 bölümünün bulunduğu görülmektedir. ${ }^{6}$ Çalışmanın giriş bölümünde bahsettiğimiz gibi bölümlerin yoğunluğuna göre ortalama olarak her bölgeden ikiş̧er tane devlet üniversitesinin müfredatı ve ders içerikleri incelenmeye özen gösterilmiştir

Bu doğrultuda Mersin Üniversitesi (Akdeniz Bölgesi), Ege Üniversitesi, Dokuz Eylül Üniversitesi (Ege Bölgesi), Boğaziçi Üniversitesi, İstanbul Üniversitesi, Trakya Üniversitesi (Marmara Bölgesi), Hacettepe Üniversitesi, Kırıkkale Üniversitesi (İç Anadolu Bölgesi), Bartın Üniversitesi, Amasya Üniversitesi (Karadeniz Bölgesi), Ağrı İbrahim Çeçen Üniversitesi (Doğu Anadolu Bölgesi), Siirt Üniversitesi, Mardin Artuklu Üniversitesi (Güneydoğu Anadolu Bölgesi) bünyesinde yer alan Çeviribilim veya Mütercim Tercümanlık Bölümlerinin müfredatında teknolojik edincini geliştirmeye katkı sağlayabilecek dersler ${ }^{7}$ ve içerikleri bu çalışmanın inceleme malzemesini oluşturmaktadır. Ele alınan dersler ve içerikleri üniversitelerin internet sayfasında yer alan bilgilere dayanarak incelenmiştir. ${ }^{8}$ İnternet sitesinde içerik bilgileri yer almayan dersler için bölümlere ve dersi veren öğretim üyelerine mail üzerinden ve telefon ile ulaşılmış, ancak bazılarından dönüş alınamamıştır. Bu durumda içerik bilgisine ulaşılamayan derslere dair ayrıntılı bir değerlendirme yapılamamıştır.

Aşağıdaki tabloda üniversitelerde teknoloji edincini geliştirmeye yönelik olduğu varsayılan dersler sunulmaktadır.

6 (Çevrimiçi), https://www.osym.gov.tr/TR,16858/2019-yuksekogretim-programlari-ve-kontenjanlari-kilavuzu. html, (3.11.2019). 2019-2020 ÖSYM tercih kılavuzundan öğrenci alımı yapan Çeviribilim/Mütercim Tercümanlık lisans programları çalışmanın ekinde ayrıca sunulmaktadır.

7 Ayrıca Uygulamalı İngilizce ve Çevirmenlik Bölümlerinde teknoloji edinicini geliştirmeye yönelik olduğu varsayılan dersleri Tuğçe Apaydın yazım süreci devam eden "Uygulamalı İngilizce ve Çevirmenlik Programlarında Çeviri Teknolojilerinin Yeri Üzerine Bir Betimleme” adlı yüksek lisans tezinde incelemeye almıştır. Lisans bölümlerinde teknoloji edincine yer veren derslere ise Halil İbrahim Balkul'un 2015 yılında kaleme aldığı “Türkiye'de Akademik Çeviri Eğitiminde Çeviri Teknolojilerinin Yerinin Sorgulanması: Müfredat Analizi ve Öğretim Elemanlarının Konuya İlişkin Görüşleri Üzerinden Bir İnceleme” başlıklı doktora tezi yer vermektedir.

8 Tabloda yer alan derslerin detaylı içeriklerine https://drive.google.com/file/d/1PFVVvZWe3QuVlSrSLgfeBJ3 $3 \mathrm{GgBzMWIL/view?usp=sharing} \mathrm{adresinden} \mathrm{ulaşabilirsiniz.}$ 


\begin{tabular}{|c|c|c|c|c|}
\hline Üniversite & Bölüm / Anabilim Dalı & Yarıyıl & Ders Adı & Zorunlu / Seçmeli \\
\hline \multirow{3}{*}{$\begin{array}{l}\text { Mersin } \\
\text { Üniversitesi }\end{array}$} & Almanca Mütercim & 5 & Çeviride Yerelleştirme I & Seçmeli \\
\hline & Tercümanlık & 6 & Çeviride Yerelleştirme II & Seçmeli \\
\hline & $\begin{array}{l}\text { Fransızca Mütercim } \\
\text { Tercümanlık }\end{array}$ & $\begin{array}{l}5 \\
6\end{array}$ & $\begin{array}{l}\text { Teknik Çeviri } \\
\text { Bilgisayar Destekli Çeviri }\end{array}$ & $\begin{array}{l}\text { Zorunlu } \\
\text { Zorunlu }\end{array}$ \\
\hline \multirow{8}{*}{$\begin{array}{l}\text { Ege } \\
\text { Üniversitesi }\end{array}$} & Almanca Mütercim & 1 & Computer & Seçmeli \\
\hline & Tercümanlık & 2 & Computer Für Fortgeschrittene & Seçmeli \\
\hline & & 7 & Programmgesteuerte Übersetzung I & Seçmeli \\
\hline & & 8 & Programmgesteuerte Übersetzung II & Seçmeli \\
\hline & İngilizce Mütercim & 1 & Computer Skills For Translators & Seçmeli \\
\hline & Tercümanlık & 5 & Translation and Technology & Seçmeli \\
\hline & & 7 & Video Game Localization & Seçmeli \\
\hline & & 8 & Localization & Seçmeli \\
\hline Dokuz & İngilizce Mütercim & 4 & Çevirmenler için Bilişim Teknolojileri & Zorunlu \\
\hline Eylül & Tercümanlık & 5 & Bilgisayar Destekli Çeviri Çalışmaları & Seçmeli \\
\hline Üniversitesi & & & & \\
\hline \multirow{7}{*}{$\begin{array}{l}\text { İstanbul } \\
\text { Üniversitesi }\end{array}$} & Almanca Mütercim & 3 & Temel Bilgi Teknolojileri I & Seçmeli \\
\hline & Tercümanlık & 4 & Temel Bilgi Teknolojileri II & Seçmeli \\
\hline & & 6 & Çeviride Bilgi Teknolojileri & Zorunlu \\
\hline & & 7 & Çeviri ve Yazı Atölyesi I & Seçmeli \\
\hline & & 8 & Çeviri ve Yazı Atölyesi II & Seçmeli \\
\hline & $\begin{array}{l}\text { Fransızca Mütercim } \\
\text { Tercümanlık }\end{array}$ & 6 & Çeviride Bilgi Teknolojileri & Zorunlu \\
\hline & $\begin{array}{l}\text { İngilizce Mütercim } \\
\text { Tercümanlık }\end{array}$ & 6 & Çeviride Bilgi Teknolojileri & Zorunlu \\
\hline Boğaziçi & Çeviribilim Bölümü & 3 & Çevirmenler için Bilişim Teknolojileri & Zorunlu \\
\hline Üniversitesi & & 4 & Yerelleştirme & Seçmeli \\
\hline & & & $\begin{array}{l}\text { Special Topics in Translation: } \\
\text { Translation Tools }\end{array}$ & Seçmeli \\
\hline & & & $\begin{array}{l}\text { Special Topics in Translation: } \\
\text { Translation Technologies }\end{array}$ & Seçmeli \\
\hline & & & $\begin{array}{l}\text { Special Topics in Translation: } \\
\text { Localization }\end{array}$ & Seçmeli \\
\hline \multirow{6}{*}{$\begin{array}{l}\text { Trakya } \\
\text { Üniversitesi }\end{array}$} & Almanca Mütercim & 3 & Temel Bilgi Teknolojileri I & Zorunlu \\
\hline & Tercümanlık & 4 & Temel Bilgi Teknolojileri II & Zorunlu \\
\hline & & 3 & Çeviride Bilgi Teknolojileri I & Seçmeli \\
\hline & & 4 & Çeviride Bilgi Teknolojileri II & Seçmeli \\
\hline & $\begin{array}{l}\text { Bulgarca Mütercim } \\
\text { Tercümanlık }\end{array}$ & $\begin{array}{l}3 \\
4\end{array}$ & $\begin{array}{l}\text { Temel Bilgi Teknolojileri I } \\
\text { Temel Bilgi Teknolojileri II }\end{array}$ & $\begin{array}{l}\text { Zorunlu } \\
\text { Zorunlu }\end{array}$ \\
\hline & $\begin{array}{l}\text { İngilizce Mütercim } \\
\text { Tercümanlık }\end{array}$ & $\begin{array}{l}5 \\
6\end{array}$ & $\begin{array}{l}\text { Çeviride Bilgi Teknolojileri I } \\
\text { Çeviride Bilgi Teknolojileri II }\end{array}$ & $\begin{array}{l}\text { Zorunlu } \\
\text { Zorunlu }\end{array}$ \\
\hline
\end{tabular}




\begin{tabular}{|c|c|c|c|c|}
\hline \multirow[t]{3}{*}{$\begin{array}{l}\text { Hacettepe } \\
\text { Üniversitesi }\end{array}$} & $\begin{array}{l}\text { Almanca Mütercim } \\
\text { Tercümanlık }\end{array}$ & $\begin{array}{l}4 \\
5 \\
6\end{array}$ & $\begin{array}{l}\text { Çeviri Araçları } \\
\text { Yerelleştirme } \\
\text { Temel Bilgi ve İletişim Teknolojileri } \\
\text { Kullanımı } \\
\text { Bilgisayar Çevirisi }\end{array}$ & $\begin{array}{l}\text { Seçmeli } \\
\text { Seçmeli } \\
\text { Zorunlu } \\
\text { Seçmeli }\end{array}$ \\
\hline & $\begin{array}{l}\text { Fransızca Mütercim } \\
\text { Tercümanlık }\end{array}$ & $\begin{array}{l}4 \\
5 \\
6\end{array}$ & $\begin{array}{l}\text { Çeviri Araçları } \\
\text { Yerelleştirme } \\
\text { Temel Bilgi ve İletişim Teknolojileri } \\
\text { Kullanımı } \\
\text { Bilgisayar Çevirisi }\end{array}$ & $\begin{array}{l}\text { Seçmeli } \\
\text { Seçmeli } \\
\text { Zorunlu } \\
\text { Seçmeli }\end{array}$ \\
\hline & $\begin{array}{l}\text { İngilizce Mütercim } \\
\text { Tercümanlık }\end{array}$ & $\begin{array}{l}4 \\
5 \\
6\end{array}$ & $\begin{array}{l}\text { Çeviri Araçları } \\
\text { Yerelleştirme } \\
\text { Temel Bilgi ve İletişim Teknolojileri } \\
\text { Kullanımı } \\
\text { Bilgisayar Çevirisi }\end{array}$ & $\begin{array}{l}\text { Seçmeli } \\
\text { Seçmeli } \\
\text { Zorunlu } \\
\text { Seçmeli }\end{array}$ \\
\hline \multirow[t]{4}{*}{$\begin{array}{l}\text { Kirıkkale } \\
\text { Üniversitesi }\end{array}$} & $\begin{array}{l}\text { Arapça Mütercim } \\
\text { Tercümanlık }\end{array}$ & 2 & Temel Bilgi ve Teknoloji Kullanımı & Seçmeli \\
\hline & $\begin{array}{l}\text { Farsça Mütercim } \\
\text { Tercümanlık }\end{array}$ & 2 & Temel Bilgi ve Teknoloji Kullanımı & Zorunlu \\
\hline & $\begin{array}{l}\text { Fransızca Mütercim } \\
\text { Tercümanlık }\end{array}$ & $\begin{array}{l}2 \\
7 \\
8\end{array}$ & $\begin{array}{l}\text { Temel Bilgi Teknolojileri Kullanımı } \\
\text { Bilgisayar Destekli Çeviri I } \\
\text { Bilgisayar Destekli Çeviri II }\end{array}$ & $\begin{array}{l}\text { Zorunlu } \\
\text { Seçmeli } \\
\text { Seçmeli }\end{array}$ \\
\hline & $\begin{array}{l}\text { İngilizce Mütercim } \\
\text { Tercümanlık }\end{array}$ & $\begin{array}{l}1 \\
4 \\
5 \\
8\end{array}$ & $\begin{array}{l}\text { Temel Bilgi Teknolojileri Kullanımı } \\
\text { Bilgisayar Destekli Çeviri } \\
\text { Çeviri Teknolojileri } \\
\text { Yerelleştirme }\end{array}$ & $\begin{array}{l}\text { Zorunlu } \\
\text { Seçmeli } \\
\text { Zorunlu } \\
\text { Zorunlu }\end{array}$ \\
\hline $\begin{array}{l}\text { Bartın } \\
\text { Üniversitesi }\end{array}$ & Çeviribilim Bölümü & $\begin{array}{l}4 \\
5 \\
6 \\
7 \\
8\end{array}$ & $\begin{array}{l}\text { Çeviri Araçları } \\
\text { Yerelleştirme } \\
\text { Çeviri Teknolojileri } \\
\text { Bilgisayar Destekli Çeviri } \\
\text { Makine Çevirisi ve Çeviride } \\
\text { Düzeltme/Son Okuma } \\
\text { Oyun Yerelleştirmesi ve Altyazı/ } \\
\text { Dublaj Çevirisi }\end{array}$ & $\begin{array}{l}\text { Zorunlu } \\
\text { Seçmeli } \\
\text { Zorunlu } \\
\text { Seçmeli } \\
\text { Seçmeli } \\
\text { Seçmeli }\end{array}$ \\
\hline $\begin{array}{l}\text { Amasya } \\
\text { Üniversitesi }\end{array}$ & $\begin{array}{l}\text { İngilizce Mütercim } \\
\text { Tercümanlık }\end{array}$ & $\begin{array}{l}5 \\
6 \\
7\end{array}$ & $\begin{array}{l}\text { Yerelleştirme I } \\
\text { Çeviri Teknolojileri } \\
\text { Bilgisayar Çevirisi }\end{array}$ & $\begin{array}{l}\text { Zorunlu } \\
\text { Zorunlu } \\
\text { Seçmeli }\end{array}$ \\
\hline $\begin{array}{l}\text { Ağrı } \\
\text { İbrahim } \\
\text { Çeçen } \\
\text { Üniversitesi }\end{array}$ & $\begin{array}{l}\text { İngilizce Mütercim } \\
\text { Tercümanlık }\end{array}$ & $\begin{array}{l}1 \\
2 \\
6\end{array}$ & $\begin{array}{l}\text { Bilgi ve İletişim Teknolojileri I } \\
\text { Bilgi ve İletişim Teknolojileri II } \\
\text { Bilgisayar Destekli Çeviri Yöntemleri }\end{array}$ & $\begin{array}{l}\text { Zorunlu } \\
\text { Zorunlu } \\
\text { Zorunlu }\end{array}$ \\
\hline $\begin{array}{l}\text { Siirt } \\
\text { Üniversitesi }\end{array}$ & $\begin{array}{l}\text { İngilizce Mütercim } \\
\text { Tercümanlık }\end{array}$ & 7 & Çeviride Özel Konular: Teknoloji & Seçmeli \\
\hline $\begin{array}{l}\text { Mardin } \\
\text { Artuklu } \\
\text { Üniversitesi }\end{array}$ & $\begin{array}{l}\text { İngilizce Mütercim } \\
\text { Tercümanlık }\end{array}$ & $\begin{array}{l}1 \\
2 \\
7\end{array}$ & $\begin{array}{l}\text { Temel Bilgi Teknolojileri-I } \\
\text { Temel Bilgi Teknolojileri-II } \\
\text { Çeviri Programları }\end{array}$ & $\begin{array}{l}\text { Zorunlu } \\
\text { Zorunlu } \\
\text { Seçmeli }\end{array}$ \\
\hline
\end{tabular}




\section{Değerlendirme}

Yukarıdaki tabloya baktığımızda Siirt Üniversitesinde doğrudan teknoloji kullanımına yönelik sadece bir ders olduğu göze çarpmaktadır. Bu nedenle bu bölümdeki derslerle ilgili ayrıntılı bir değerlendirme yapmak zorlaşmaktadır. Bu dersin oldukça geç bir dönemde (7. yarıyıl) ve seçmeli olarak verildiği görülmektedir. Seçmeli derslerin dönemlere göre açılma durumları değişkenlik gösterebildiği ve bütün öğrenciler tarafından seçileceği kesin olmadığı için, teknoloji edincinin tüm öğrencilere sadece seçmeli dersler yoluyla kazandırılamayacağı göz önünde bulundurulmalıdır. Ancak müfredat planı üzerinden bu bölümdeki diğer derslerin öğrencilerin teknoloji kullanımına katkı sağlayıp sağlamadığı konusunda net bir bilgiye ulaşılamamıştır.

Mersin Üniversitesi Almanca Mütercim Tercümanlık Bölümünün 8 yarıyıllık ders müfredatında, çeviri teknolojilerinin önemli bir alt alanını oluşturan yerelleştirme konusuna dair seçmeli derslerin iki dönem boyunca olduğu gözlemlenmektedir. Ancak yerelleştirme derslerinden önceki yarıyıllarda temel teknoloji kullanımına yönelik herhangi bir derse rastlanmamaktadır. Fransızca Mütercim Tercümanlık Bölümünde 5. yarıyılda zorunlu olarak Teknik Çeviri dersinin verildiği ve yine öncesinde direkt teknolojiyi konu alan herhangi bir ders olmadığını söylemek olanaklıdır. Dersin adının teknolojiyle birebir bağlantılı olmamasına rağmen, ders içeriklerine göre bu derste çeviri teknikleri, makine çevirisi, bilgisayar destekli çeviri ve terminoloji yönetimi ele alınması amaçlanmıştır. 6. Yarıyılda zorunlu olarak Bilgisayar Destekli Çeviri dersinin okutulduğu gözlenmektedir. Dolayısıyla Mersin Üniversitesinin müfredat planına göre yerelleştirme ve bilgisayar destekli çeviri araçlarında yoğunlaştığını belirtmek mümkündür.

Ege Üniversitesi Almanca Mütercim Tercümanlık Bölümünde derslerin erken dönemlerde verilmeye başlanmasını, öğrencilere teknoloji kullanımını aşılamak için olumlu bir girişim olarak değerlendirebiliriz. Ancak bütün bu derslerin sadece seçmeli olduğu düşünülürse, derslerin kesin olarak açılması konusunda bir netlik bulunmaması söz konusudur. Ayrıca bütün öğrencilerin ilgili dersleri seçme eğilimleri olmayacağından ${ }^{9}$, teknoloji edincinin kazandırılması bu noktada oldukça zorlaşacaktır. Son olarak bu derslerin okutulduğu dönemler arasındaki uzun süre, teknoloji edincinin kazanılıp geliştirilmesi konusunda dezavantajı bir durum olabilir. İngilizce Mütercim Tercümanlık Bölümünde de derslerin sadece seçmeli olduğu gözlemlenmektedir. Teknoloji konusunu ele alan toplamda dört ders bulunmaktadır ve dersler konusunda da farklı alternatifler sunulduğu görülmektedir.

Dokuz Eylül Üniversitesinin ders planında ise, derslerde 4. yarıyılda zorunlu olarak temel teknoloji kullanımının ele alınıp 5. yarıyılda bilgisayar destekli çalışmalarla bu bilgilerin çeviriye uygulandığının söz konusu olduğunu tablodan yola çıkarak varsayabiliriz. Bölümün müfredatında doğrudan teknolojiyi konu alan bir başka derse rastlanmamıştır.

İstanbul Üniversitesi Almanca Mütercim Tercümanlık Bölümünde, önce iki dönem boyunca temel teknoloji kullanımının ele alınıp ardından bu teknolojilerin çeviriye uygulandığı ve atölye

9 Ege Üniversitesi Almanca Mütercim Tercümanlık Bölümü seçmeli dersler için bkz. (Çevrimiçi) https://translation. ege.edu.tr/tr-4827/almanca_mutercim-tercumanlik_lisans_programi.html, (1 Temmuz 2019). 
dersleri ile desteklendiği gözlemlenmektedir. Çeviri ve Yazı Atölyesi dersinin içeriğine göre farklı alanlara ait özgün bilimsel ve kullanmalık metin örneklerinin, biçem, dil, söylem ve metin gelenekleri açısından incelenmesi, benzer örneklerin üretilmesi ve çevrilmesi dersin asıl amacı olsa da, bu derste bilgisayar ve çeviri programlarının kullanılması teknoloji edincini destekler nitelikte bir ders olduğunu göstermektedir. Ancak bu bölümde temel teknoloji kullanımına yönelik derslerin seçmeli olması, temel bilgilerin öğrenimini bütün öğrenciler üzerinde mümkün kılmamaktadır. Bölümde teknoloji edincini geliştirmeye yönelik derslere yoğun şekilde yer verildiği plan üzerinden tespit edilebilmektedir. Ancak bu derslerin ağırlıklı olarak seçmeli dersler olduğu görülmektedir. Söz konusu seçmeli derslerin açılmadığı durumda doğrudan teknolojiyi konu alan bir dersin olduğu görülmektedir. Fransızca ve İngilizce Mütercim Tercümanlık bölümlerinde 8 yarıyıllık planında 6 . yarıyılda zorunlu olarak okutulan teknoloji bilgisine ve kullanımına yönelik bir dersin bulunduğu da gözlemlenmektedir. Dolayısıyla İstanbul Üniversitesinde ilgili derslere anabilim dallarına göre farklı yoğunlukta yer verildiğini söyleyebiliriz. Ayrıca üç anabilim dalında 5. yarıyılda zorunlu olarak verilen Çeviride Araştırma Yöntemleri dersinde bilgisayarla araştırma, çevrimiçi kaynakları arama vb. konulara da değinildiği için bu dersin dolaylı olarak teknoloji edincini destekler nitelikte olduğu varsayılabilir.

Boğaziçi Üniversitesi Çeviribilim Bölümüne baktığımız zaman teknoloji edincini konu eden beş ders görünmektedir. İlki 3. yarıyılda zorunlu olarak verilen Çevirmenler için Bilişim Teknolojileri dersidir. Ders kapsamında başlıca dil teknolojilerinin ve bunların tarihi gelişimleri, yaygın olarak kullanılan kelime işlemcileri ve çeviri yazılımlarının kullanılması gibi konular ele alınmaktadır. Seçmeli ders olan Yerelleştirme dersinde ise yerelleştirme, çeviri bellekleri ve terminoloji yönetimi gibi konular ele alınmaktadır. Bir diğer seçmeli dersler de Special Topics in Translation: Translation Tools (Çeviride Özel Konular: Çeviri Araçları), Special Topics in Translation: Translation Technologies (Çeviride Özel Konular: Çeviri Teknolojileri), Special Topics in Translation: Localization (Çeviride Özel Konular: Yerelleştirme) ${ }^{10}$ olarak sıralanabilir.

Trakya Üniversitesi Almanca Mütercim Tercümanlık Anabilim Dalının ders müfredatında teknoloji kullanımına yönelik hem zorunlu hem de seçmeli derslerin yer aldığı tablodan gözlemlenmektedir. Ancak bu derslerin sadece iki dönem boyunca verilmesi ve sonraki dört dönem boyunca teknoloji kullanımına yönelik derslerin bulunmaması da söz konusudur. Bulgarca Mütercim Tercümanlık Anabilim Dalında zorunlu olarak iki dönem boyunca temel teknoloji kullanımına yönelik derslerin okutulduğu ve sonraki dönemlerde teknoloji kullanımına yönelik başka derslerin yer almadığg 1 görülebilmektedir. Bu konuyla ilgili olarak Balkul'un çalışmasındaki 2014-2015 verilerine göre, bölümün müfredatında çeviri teknolojileri ile ilgili hiçbir ders bulunmadığ 1 göz önünde bulundurulursa ${ }^{11}$ bu bölümde son yıllarda teknoloji

10 Boğaziçi Üniversitesinde seçmeleri derslerin tüm sınıflar tarafından alınabileceğini ancak buradaki derslerin ağırlıklı olarak 3. ve 4. sınıflar tarafından seçildiği bilgisi üniversiteden alınmıştır.

11 Bkz. Balkul, H.İ. (2015). Türkiye'de Akademik Çeviri Eğitiminde Çeviri Teknolojilerinin Yerinin Sorgulanması: Müfredat Analizi ve Öğretim Elemanlarının Konuya İlişkin Görüşleri Üzerinden Bir İnceleme, Doktora Tezi, Sakarya Üniversitesi Sosyal Bilimler Enstitüsü, Sakarya. 
alanına yönelik derslerde düzenlemeye gidildiği söylemek olanaklıdır. Üniversitenin Almanca ve Bulgarca Mütercim Tercümanlık Bölümlerinin ders müfredatına göre, Bil 117 Temel Bilgi Teknolojileri I ve Bil 118 Temel Bilgi Teknolojileri II zorunlu ders olarak ve farklı dönemlerde okutulmaktadır. Dersin koduna bakıldığı zaman bu dersin başka bölüm hocası tarafından verildiği de düşünülebilir. Müfredat planı üzerinden yapılan araştırmalara göre bu derslerin Teknik Bilimler Meslek Yüksekokulu ve Fizik Bölümünün dersi olduğu tespit edilmiştir. ${ }^{12}$ Almanca bölümünde teknoloji kullanımı seçmeli derslerle desteklenirken, Bulgarca bölümünün temel teknoloji eğitimi dersi dışında doğrudan teknolojinin konu alındığı bir derse yer vermediği tablodan görülebilir. İngilizce Mütercim Tercümanlık Anabilim Dalında ise zorunlu olarak iki dönem boyunca çeviride kullanılan bilgi teknolojileri hakkında bilgi edinmeyi amaçlayan Çeviride Bilgi Teknolojilerine yer verilmiştir. Müfredat planında doğrudan teknoloji kullanımını ele alan başka bir ders görülmemektedir.

Hacettepe Üniversitesi Almanca, Fransızca ve İngilizce Mütercim Tercümanlık Anabilim Dallarında aynı dönemde ortak olarak BEB 650 Temel Bilgi ve İletişim Teknolojileri Kullanımı ${ }^{13}$ dersi yer almaktadır. Araştırmalar neticesinde üniversitenin Bilişim Enstitüsü Web Birimine ait internet sayfası üzerinden uzaktan okutulan ve üniversitenin bütün bölümlerinde yer alan bir ders olduğu bilgisine ulaşılmıştır. Bu dersin çalışma kapsamında incelenen dersler arasında uzaktan eğitim olarak verilen tek ders olduğu gözlemlenmektedir. Müfredat planına göre dersin amacı bilgi teknolojileri ana kavramlarına sahip olarak kişisel bilgisayar kullanımında yetkinlik kazandırmaktır. Bir başka deyişle bu derste temel bir bilgisayar kullanımı eğimi sunulmaktadır. Üç anabilim dalının ders planında da aynı dönemlerde Çeviri Araçları, Yerelleştirme ve Bilgisayar Çevirisi dersleri mevcuttur, ancak daha öncede farklı üniversiteler için belirttiğimiz gibi bu derslerin seçmeli dersler olduğu düşünülürse, derslerin açılmama ihtimali ve tüm öğrenciler tarafından seçilmeme durumu söz konudur.

Kırıkkale Üniversitesinde Arapça, Farsça ve Fransızca Mütercim Tercümanlık Anabilim Dallarında bilgisayarla ilgili temel yazılım ve donanım hakkında bilgi vermek amacıyla, ENF 101 Temel Bilgi Teknolojileri Kullanımı dersi 2. yarıyılda, İngilizce Mütercim Tercümanlıkta ise 1. yarıyılda bölüm hocaları tarafından okutulmaktadır. Yine Balkul'un tezinde yer alan 2014-2015 akademik yılı verilerine göre Kırıkkale Üniversitesinde Arapça ve Farsça Mütercim Tercümanlık Anabilim Dallarında teknolojiyi konu alan bir ders bulunmamaktadır (Balkul, 2015:106-107). Dolayısıyla bu anabilim dallarında teknoloji edinci sağlayacak dersler konusunda gelişim gösterdiğini söylemek doğru olacaktır. Fransızca Mütercim Tercümanlıkta ise bu temel eğitim dersinden sonra 7. ve 8. yarıyılda müfredata seçmeli dersler eklemiştir, ancak temel eğitim sunulan ders ile bu seçmeli dersler arasındaki sürenin bilgilerin pekiştirilebilmesi için uzun olabileceği de mümkündür. Tablodan da görüleceği gibi, İngilizce Mütercim Tercümanlık Anabilim Dalının ise diğer anabilim dallarına göre teknoloji kullanımına yönelik dersleri

12 Bu konu ile ilgili bölüm öğrencilerinden de bilgiler alınıp derslerin Teknik Bilimler Meslek Yüksekokulu ve Fizik Bölümü hocaları tarafından okutulduğu doğrulanmıştır.

13 Dersin tanıtım sayfası için bkz. (çevrimiçi), http://beb650.bilisim.hacettepe.edu.tr/, (17.02.2020) 
çeşitlendirdiği ve seçmeli dersler açıldığı durumlarda verilen bu temel teknoloji eğitimini çeviri eğitimi açısından desteklemeyi amaçladığı varsayılabilir. Ayrıca Kırıkkale Üniversitesindeki anabilim dalları arasında teknoloji eğitimi konusunda benzer bir plan olmadığını da söyleyebiliriz.

Bartın Üniversitesinde 4. yarıyılda klasik ve dijital çeviri araçları hakkında çevirmen adaylarını kuramsal olarak bilgilendirme amaçlı zorunlu olarak Çeviri Araçları dersi bulunmaktadır. $\mathrm{Bu}$ dersin hemen ardından ard arda her dönem okutulan toplamda altı tane teknoloji dersi gözlemlenmektedir. Bölümde zorunlu ve seçmeli olarak çeşitli teknoloji kullanımını konu eden derslere yer vermektedir. Ayrıca Bartın Üniversitesi diğer üniversitelerden farklı olarak çeviri teknolojilerinin önemli uzmanlık alanlarından biri olan Makine Çevirisi ve Çeviride Düzeltme/Son Okuma adlı derse yer vermektedir. Ders kapsamında düzelti ve redaksiyon hakkında bilgi ve becerilerin geliştirmesi amaçlanmaktadır. Amasya Üniversitesinin ders müfredatına göre, zorunlu bir çeviri teknolojileri eğitiminden hemen sonra seçmeli derslerle teknoloji kullanımının desteklendiğini söylemek mümkündür. Hem Bartın hem de Amasya Üniversitesinin aynı yarıyılda çeviri teknolojilerinin önemli uzmanlık alanlarından biri olan yerelleştirme, çeviri teknolojileri ve bilgisayar çevirisi konularına yer verdikleri görülmektedir.

Ağrı İbrahim Çeçen Üniversitesi İngilizce Mütercim Tercümanlık Bölümünde teknoloji eğitimini destekleyen üç dersin okutulduğu tablodan anlaşılmaktadır. Bütün bu dersler öğrencilere zorunlu olarak sunulmaktadır. Ancak ilk iki dönemde verilen temel teknoloji dersi üzerinden uzun süre geçtikten sonra 6 . dönemde bilgisayar üzerinden çeviri dersi verildiği de gözlemlenmektedir.

Son olarak Mardin Artuklu Üniversitesi İngilizce Mütercim Tercümanlık Bölümü, müfredat planının ilk iki döneminde temel bir teknoloji eğitimine zorunlu olarak yer vermektedir. Ancak ders planına göre ilk iki dönem verilen bu ders üzerine yedinci dönemde yer alan Çeviri Programları dersine kadar herhangi bir teknoloji kullanımını içeren bir ders verilmemektedir. Bu durumda derslerin birbirini desteklemesi açısından kısa ya da uzun bir arayla okutulması ayrıca üzerinde tartışılması gereken bir olgudur.

İncelemeye alınan 13 devlet üniversitesinin farklı dillerdeki 24 bölümüne veya anabilim dalına ait müfredatlardan ve ders içeriklerinden yola çıkarak uygulamalı veya kuramsal olarak doğrudan teknoloji eğitimini barındıran toplamda 71 dersin izlencesi incelenmiştir. Teknolojiyi konu alan derslere en çok yer verenin Bartın Üniversitesi Çeviribilim Bölümü (mevcut 6 ders); en az yer verenin ise Siirt Üniversitesi İngilizce Mütercim Tercümanlık Anabilim Dalı (mevcut 1 ders) olduğunu söyleyebiliriz. Ancak sadece müfredat planı üzerinden teknoloji edincinin bu bölümlerdeki diğer derslerde kazandırılması/geliştirilmesi konusuna dair net bir tespitte bulunmamız mümkün değildir.

Teknoloji edinci içindeki birimler müfredat planında dört kategori üzerinden karşımıza çıkmaktadır:

1. Temel Bilgi Teknolojileri/ Temel Bilgi ve İletişim Teknolojileri Kullanımı/ Temel Bilgi ve Teknoloji Kullanımı (Toplam 12 anabilim dalında mevcut) 
2. Bilgisayar Destekli Çeviri/ Bilgisayar Destekli Çeviri Çalışmaları/ Bilgisayar Çevirisi/ Bilgisayar Destekli Çeviri Yöntemleri/Çeviri Programları (Toplam 12 anabilim dalında mevcut)

3. Yerelleştirme (Toplam 10 anabilim dalında mevcut)

4. Çeviride Bilgi Teknolojileri/Çevirmenler için Bilişim Teknolojileri/ Computer Skills For Translators (Toplam 8 anabilim dalında mevcut)

Yukarıda gördüğümüz dört kategoriden birincisi çeviri öğrencilerine başlıca verilmesi gerektiğini düşündüğüm Temel Bilgi Teknolojileri/ Temel Bilgi ve İletişim Teknolojileri Kullanımı/ Temel Bilgi ve Teknoloji Kullanımı dersidir. Bu dersin toplamda 12 (10 zorunlu/2 seçmeli) anabilim dalında ve ağırlıklı olarak zorunlu şekilde okutulduğunu görmekteyiz (bkz. Tablo 2). Ders içeriklerini incelediğimizde bu derste genel olarak bilgisayar, tablet, akıllı telefon gibi cihazlar hakkındaki genel bilgiler ve işletim sistemleri, internet, web tarayıcılar, işlem tabloları, sunu hazırlama, resim ve çizim programları, Windows ve MS Office sürümlerinin kullanım bilgisi sunulmaktadır. Dolayısıyla makaledeki geniş anlamda teknoloji edinci tanımından yola çıkarak, temel bir teknoloji eğitimi ve teknolojik araçların kullanım bilgisini sunduğu için bu dersin teknoloji edinci kazandırma konusunda ilk basamak olduğunu varsayabiliriz.

Çeviri teknolojileri derslerinin görece önemli alt alanlarından biri olan Bilgisayar Destekli Çeviri/ Bilgisayar Destekli Çeviri Çalışmaları/ Bilgisayar Çevirisi/ Bilgisayar Destekli Çeviri Yöntemleri/Çeviri Programları dersi ise ikinci kategoride yer almaktadır. Dersin toplamda 12 (2 zorunlu/10 seçmeli) bölümde ve yüksek oranda seçmeli olarak yer aldığını gözlemleyebiliriz (bkz. Tablo 2). İçeriklere göre genel olarak dersin amacı bilgisayar destekli çeviri hakkında öğrencileri bilgilendirmek ve çeviri programları kullanarak çeviri uygulamaları yaptırmaktır. Bu çerçevede derslerde ağırlıklı olarak SDL Trados ile çalışmalar yürütüldüğü bilgisi yer almaktadır. Teknoloji edinci ile ilişkilendirdiğimiz zaman çeviriye yardımcı yazılımların bilgisi (özellikle çeviri programları) bu ders kapsamında sunulmaktadır.

Üçüncü kategoride içerik bilgisine göre ağırlıklı olarak yerelleştirme sürecinde göz önünde bulundurulması gereken etmenlerin aktarıldığ Yerelleştirme dersi yer almaktadır ve bu ders 10 ( 2 zorunlu/8 seçmeli) anabilim dalında mevcuttur (bkz. Tablo 2). İkinci kategoride tarif edildiği haliyle Trados programı üzerinde çalışıldığına göre aynı derste yerelleştirmeye yönelik çalışmaların da gerçekleştirildiğini söyleyebiliriz. Dolayısıyla bu iki kategoride yer alan dersleri tek bir ders altında birleştirmemiz mümkündür. Ayrıca Ege Üniversitesi İngilizce Mütercim Tercümanlık Bölümü ve Bartın Üniversitesi Çeviribilim Bölümünde yerelleştirmenin de alt alanı olarak değerlendirebileceğimiz oyun yerelleştirme derslerinin seçmeli olarak yer aldığı gözlemlenmektedir.

Çeviride Bilgi Teknolojileri/Çevirmenler için Bilişim Teknolojileri/ Computer Skills For Translators (Çevirmenler için Bilgisayar Becerileri) dördüncü kategoride yer almaktadır. Ele alınan bölümlerden 8 tanesi ( 6 zorunlu/2 seçmeli) tarafından öğrencilere okutulmaktadır. 
Bu ders kapsamında, içeriklere göre bilgi teknolojileri kavramından hareketle bilgisayarın ve buna bağlı olarak internetin çeviri alanındaki kullanım olanaklarının öğrencilere tanıtılması amaçlanmaktadır. Bu anlamda temel teknoloji eğitiminin çeviriye dâhil edilmesini sağlayan ana derslerden biri olduğunu söylemek mümkündür.

Tabloda yer alan Çeviri ve Yazı Atölyesi, Teknik Çeviri ${ }^{14}$ derslerinin adları her ne kadar teknolojiyi konu almasa da, içeriklerine baktığımızda derslerin işleyişinde teknoloji aracılığıyla eğitim sunulduğu için bu dersler teknoloji edincine katkı sağlamaktadır. Değerlendirme bölümünün bu kısmına kadar doğrudan teknoloji eğitimini konu alan dersler üzerinde durulmuştur. Ancak bölümlerin müfredatında direkt teknoloji eğitimini konu almasa da dersin işleyişinde teknolojiden yararlanılması ve teknolojinin ders işleyişinde araç olarak kullanılması da teknoloji edincini etkilemektedir. Örneğin Çeviride Araştırma Yöntemleri dersi teknoloji eğitimine odaklanmadan sunulur ancak bilgisayarla işlem yapmak, arama motorları, koşut metinleri taratma, internet kullanımı vb. bilgileri sağladığı için dolaylı olarak teknoloji edincine katkı sağlamaktadır. Bu anlamda bu gibi derslerin her ne kadar müfredat planlarında açıkça yazmasa da teknoloji edincini geliştirmeye etkisi olduğu söylenebilir. Son olarak yukarıda incelenen ders adlarında farklılaşmalar görülse de ders içeriklerinde büyük oranda benzerlik olduğu söylenebilir.

\section{Sonuç ve Öneriler}

Türkiye'de aktif olarak çeviri eğitimi veren 27 devlet üniversitesinden (farklı dillerde 43 bölümü mevcut) 13 tanesi bu çalışma kapsamında incelemeye alınmıştır. Söz konusu 13 üniversitenin 24 bölümünde veya anabilim dalında okutulan derslerin dağılımına baktığımızda yaklaşık \% 97'sinin teknoloji eğitimi barındırmayan dersleri ve \% 3'ünün teknolojiyi konu alan dersleri oluşturduğunu söylemek mümkündür. ${ }^{15} \% 3$ oranındaki bu dersler, bölümlerin veya anabilim dallarının müfredatında teknoloji kavramına yer veren ders adlarına ve bu derslerin içeriklerine göre tespit edilmeye çalışmıştır. Ancak bu süreçte ders içeriklerinin hepsine ulaşılamamıştır. Ayrıca içeriğinde teknoloji eğitimine yer verdiği varsayılan derslere de yer verilmiştir.

Yukarıdaki tabloda teknoloji kullanımını veya geliştirilmesini konu alan toplam 71 ders (41 tanesi seçmeli, 30 tanesi zorunlu) olduğunu görülmektedir. Bu dersleri teknoloji edinci içindeki tanımlardan yola çıkarak dört kategori üzerinde değerlendirmemiz mümkündür. Kategoriler temel teknoloji eğitimi, çeviride teknoloji eğitimi, yerelleştirme ve bilgisayar destekli çeviri eğitimi sunan dersler olarak sıralanabilir. Yerelleştirme ve bilgisayar destekli çeviri eğitimi sunan derslerin içeriğinde benzer amaçlar olduğundan aynı kategoride değerlendirilmeleri mümkündür.

14 Çeviri ve Yazı Atölyesi dersi içeriğinde açıkça teknoloji kullanıldığı bilgisi yer almamaktadır ancak bu derse katılım sağlanarak kullanıldığı bilgisine ulaşılmıştır. Teknik Çeviri dersinin içeriğinde ise çeviri teknikleri ve makine çevirisi çalışıldığı bilgisi açıkça yer almaktadır.

15 Burada genel bir değerlendirme yapılmıştır ancak bu oran bir bir başka çalışmada tek tek her program içinde değerlendirilebilir. 
İlk kategorideki temel düzeydeki bilgisayar derslerinin zorunlu olarak okutulması sebebiyle öğrencilerin hepsinin bu temel eğitimi aldığı düşünülebilir. Dolayısıyla temel bilgi teknolojilerinin eğitiminin teknoloji edinci kazandırma yolunda başlıca amaç olduğu varsayılabilir. Ayrıca bu dersler temel eğitim sağlayacağından dolayı teknoloji alanındaki ilgili bölümlerin uzman hocaları tarafından okutulabilir. Hacettepe üniversitesindeki gibi (BEB 650 Temel Bilgi ve İletişim Teknolojileri Kullanımı) özellikle temel eğitim sunan derslerin uzaktan eğitimle verilmesi bu çalışma dışında ayrıca tartışılması gereken ayrı bir olgudur, ancak göz ardı edilmemesi gerekmektedir. Çünkü bu tür bir tartışma ilerleyen süreçlerde ders verme şekline de etki edebilir. Bu anlamda özellikle mekân ve donanım sorunu yaşanan üniversitelerde uzaktan eğitim dersleri artırılarak öğrencilere sunulabilir.

Bilgisayar destekli çeviri ve yerelleştirme derslerinin çalışma sonucunda ağırlıklı olarak seçmeli olduğu gözlemlenmektedir. Bu derslerin de teknoloji edincini oluşturan kategorilerden biri olduğu düşünülürse, müfredatlarda zorunlu (uzaktan eğitim) olarak verilmeleri konusu tartışmaya açılabilir. Yukarıda belirttiğimiz gibi üniversitelerde özellikle seçmeli derslerin okutulup okutulmadığg, her dönem açılıp açılmadığg konusunda bir netlik olmadığı için teknoloji edincini geliştirmede seçmeli derslerin katkısı bir başka tartışma konusunu oluşturmaktadır.

Ders müfredatlarında teknoloji eğitimini direkt olmasa da dolaylı olarak destekleyebilecek ders çeşitliliği, öğrencilerin bu alana ilgi duymasını sağlayabilecektir. Böylece mezun olduktan sonra farklı alanlarda çalışan öğrencilere bir imkân sunulmuş olacaktır. Her alanda olduğu gibi çeviri eğitiminde teknoloji alanına gereken önem verilmeye çalışılmalıdır. Üniversiteler öğrencilerin teknoloji edinci ile eğitim gördükleri program ve çevirmenlik mesleği arasında ilişki kurmaları konusunda destek olmalıdır. Ancak çeviride teknoloji kullanımında ilerlemek ve güncel teknolojilerden haberdar olmak konusunda öğrencilere de büyük görev düşmektedir. Öğrenciler aldıkları temel bilgileri kendi çalışmalarıyla ilerletmelidir. Canım Alkan bu konuyla ilgili olarak çevirmen adaylarının teknolojik donanımlarını artırmak için staj, mesleki eğitim, kendi kendine eğitim gibi başka eğitim bileşenlerinden de yararlanmasının son derece önemli olduğunu vurgulamaktadır ( Canım-Alkan, 2013:146).

Üniversitelerde akademik çeviri eğitiminin ilke ve amaçları, çalışma alanları, okutulan ders saatleri ve maddi imkânlar gibi daha birçok değişkenin göz önünde bulundurularak müfredatların oluşturulduğu gözden kaçırılmamalıdır. Ancak tümüyle çeviri piyasasına kapalı bir eğitim modeli sürdürmek de söz konusu olmamalıdır. Günümüzde bilgisayar destekli çeviri araçlarının aktif kullanımı özellikle çeviri piyasasının başlıca beklentilerinden biridir. Bütün programların işletim bilgisi ve uygulamasının üniversiteler tarafından sağlanması elbette mümkün değildir. Ancak üniversiteler teknolojik araç ve kaynaklar konusunda kavramsal ve yöntemsel bilgiyi öğrencilere sağladığında, öğrenciler karşılarına çıkan farklı araçlara uyum sağlayabilecek ve hangi aracı hangi amaçla kullanmaları gerekeceğine karar verebileceklerdir. Kurultay’a göre çeviri eğitimi çeviri sorumluluğunu üstlenme becerisini ve güvenini kazandıran eğitim olmalıdır. “Gelişmiş bir yöntem bilgisi, hazır çözümlerin olmadığı yerde yolunu 
bulmaya yarar. Bazı bilgilerin eksik olduğu yerde çatıyı iyi kurarak boşluklar doldurulabilir dolayısıyla çatı bilgisinin sağlam olması gerekir. İşte bunun için çeviri eğitimi 4 yıllık eğitim sürecini ayrıntılandırarak bu sonucu elde etmeyi hedeflemektedir"(Kurultay, 1998: 323). Bütün araçlar yerine en azından bir tane bilgisayar destekli çeviri aracı üzerinden bir eğitim sunmak, öğrencilerin diğer bilgisayar destekli araçlarla bağlantı sağlamasına fayda sağlayabilir. Çeviri edinci daha önce de ifade ettiğimiz gibi bir kaç bileşenden oluşan bir yapıya sahiptir ve teknoloji edinci bunlardan sadece biridir. Ancak gelişen ve sürekli değişen teknolojiden etkilenen çevirmen ve çeviri eğitimi için, teknoloji edinci göz ardı edilemeyecek konuma yükselmeyi sürdürmektedir.

Hakem Değerlendirmesi: Dış bağımsız.

Çıkar Çatışması: Yazar çıkar çatışması bildirmemiştir.

Finansal Destek: Yazar bu çalışma için finansal destek almadığını beyan etmiştir.

Peer-review: Externally peer-reviewed.

Conflict of Interest: The author has no conflict of interest to declare.

Grant Support: The author declared that this study has received no financial support.

\section{KAYNAKÇA/REFERENCES}

Akalın, R. ve Gündoğdu, M. (2010). Akademik çeviri eğitiminin temel ilkeleri üzerine düşünceler: Uygulanan ders izlenceleri bağlamında hedefler ve beklentiler. Mersin Üniversitesi Ĕ̈itim Fakültesi Dergisi, 6(1), 79-93.

Akbulut, A. N. (2004). Söylenceden gerçekliğe. İstanbul: Multilingual.

Akbulut, A. N. (2006). Çeviri Eğitimi. (çevrimiçi) http://ceviribilim.com/?p=229, 6 Şubat 2020

Akdağ, A. I. (2015) Mütercim Tercümanlık Öğrencilerinde Çeviri Edincinin Ölçülmesi ve Değerlendirilmesi, Doktora Tezi, İstanbul Üniversitesi, İstanbul (yayımlanmamış).

Ammann, M. (2008) Akademik çeviri eğitimine girişs. (E. Deniz Ekeman Çev.). İstanbul: Multilingual.

Aslan, E. (2015) Çeviri Teknolojilerinin Çevirmenin Sınırlarını Belirlemedeki Rolü, V. Uluslararası Karşılaştırmalı Edebiyat Bilimi Kongresi bildiri kitabı, Mersin Üniversitesi yayınları, 697-703.

Aslan, E. (2016) Geçmişten Günümüze Çeviri Teknolojileri, 2016 Hoca Ahmet Yesevi Yı1ı Anısına Uluslararası Türk Dünyası Eğitim Bilimleri ve Sosyal Bilimler Kongresi, 419-424.

Bakır, G. R. (2012) Yazılımda Yerelleştirme ve Çeviri, Yüksek Lisans Tezi, Sakarya Üniversitesi Sosyal Bilimler Enstitüsü, Sakarya (yayımlanmamış).

Balkul, H. İ. (2015) Türkiye'de Akademik Çeviri Eğitiminde Çeviri Teknolojilerinin Yerinin Sorgulanması: Müfredat Analizi ve Öğretim Elemanlarının Konuya İlişkin Görüşleri Üzerinden Bir İnceleme, Doktora Tezi, Sakarya Üniversitesi Sosyal Bilimler Enstitüsü, Sakarya (yayımlanmamış).

Berk, Ö. (2005) Kuramlar ışığında açıklamalı çeviribilim terimcesi. İstanbul: Multilingual

Canım-Alkan, S. (2013). Lisans düzeyinde çeviri eğitiminde teknoloji eğitiminin yeri. İ.Ü. Çeviribilim Dergisi, 7, 127-147.

Canım, S. (2008) Türkiye'de Çeviri Bürolarında Web Sitesi Yerelleştirmeleri ve Bu Süreçte Bilgi Teknolojilerinin Kullanımı, Yüksek Lisans Tezi, İstanbul Üniversitesi Sosyal Bilimler Enstitüsü (yayımlanmamış). 
Çetiner, C. (2015) Kırıkkale Üniversitesi İngilizce Mütercim-Tercümanlık Anabilim Dalı Öğrencilerinin Çeviri Teknolojilerine Yönelik Tutumlarının İncelenmesi, Yüksek Lisans Tezi, Kırıkkale Üniversitesi Sosyal Bilimler Enstitüsü, (yayımlanmamış).

Çoban, F. (2013) Çeviri Edinci: Yazılı ve Sözlü Çevirmenin Sahip Olması Gereken Beceri ve Yeteneklerin Genel Çeviri Kuramları Işı̆̆ında İncelenmesi, Yüksek Lisans Tezi, Sakarya Üniversitesi Sosyal Bilimler Enstitüsü, (yayımlanmamış).

Demez, N. (2014) Türkiye'de Çeviribilimin Gelişimi Açısından Paradigma Kavramı ve Değişiminin Yansımaları, Doktora Tezi, İstanbul Üniversitesi Sosyal Bilimler Enstitüsü, (yayımlanmamış).

Durukan, E. ve Çelikay, K. (2018). Çeviri edincine yönelik kapsayııı bir tanım önerisi. Turkish Studies Dergisi, $13 / 12,161-176$.

Ersoy, H. ve Balkul, H. İ. (2012). Teknolojik gelişmelerin çevirmen ve çeviri mesleği açısından olumlu ve olumsuz etkileri: Çeviri alanında yeni yaklaşımlar. Akademik Incelemeler Dergisi, 7(2), 295-307.

Eruz, S. (2003. Çeviriden çeviribilime. İstanbul: Multilingual.

Eruz, S. (2008). Akademik çeviri ĕgitimi. İstanbul: Multilingual.

Eser, O. (2013. Çeviri Eğitiminde Edinç Kavramının Değerlendirilmesi, İstanbul Üniversitesi Sosyal Bilimler Enstitüsü, Doktora Tezi, (yayımlanmamış).

Fraser, J. (2000). The Broader View: How Freelance Translators Define Translation Competence', Developing Translation Competence, Amsterdam/ Philadelphia: John Benjamins, ss. 51-62.

Göktürk, A. (2013). Çeviri: Dillerin dili. İstanbul: Yapı Kredi Yayınları.

Göpferich, S. (2008). Translations-prozessforschung Stand Methoden Perspektiven, Tübingen: Gunter Narr Verlag.

Haldan, A. (2016). Çeviri Ĕgitiminde Çeviri Edinci Geliştirme Alışkanlıkları, İstanbul Üniversitesi Sosyal Bilimler Enstitüsü, Doktora Tezi, (yayımlanmamış).

Kurultay, T. (1998). Çeviri ĕgitimi neden farklı bir ĕgitimdir? Çeviri Bölümlerinin Programlarında Yöntem Derslerinin Gerekliliği ve Uygulanma Koşulları, Mersin Üniversitesi Yayını, 307-324.

Neubert, A. (2000). 'Competence in Language, in Languages, and in Translation', Developing Translation Competence, Amsterdam/ Philadelphia: John Benjamins, ss. 3-17.

Öztürk, E. (2013) Yerelleştirme ve Çeviri: Çeviribilimde Ve Çeviri Eğitiminde Yerelleştirmenin Konumu, Yüksek Lisans Tezi, Sakarya Üniversitesi Sosyal Bilimler Enstitüsü, Sakarya (Yayımlanmamış).

PACTE. (2000). Acquiring translation competence. Hypotheses and methodological problems in a reseach Project. Investigating Translation. A. Beeby, D. Ensinger \& M. Presas (Eds.). İnvestigating Translation: Selected Papers from the 4th International Congress on Translation, Barcelona 1998 içinde (s. 99-106). Amsterdam: John Benjamins.

Presas, M. (2000). 'Bilingual Competence and Translation Competence', Developing Translation Competence, Amsterdam/ Philadelphia: John Benjamins, ss. 19-31.

Schaeffner, C. \& Adab, B. (2000). 'Developing Translation Competence: Introduction', Developing Translation Competence, Amsterdam/Philadelphia: John Benjamins.

Şahin, M. (2013). Çeviri ve teknoloji. İzmir: İzmir Ekonomi Üniversitesi Yayınları.

Tahir-Gürçağlar, Ş. (2011). Çevirinin ABC'si. İstanbul: Say Yayınları.

Tok, Z. (2019) Bilgisayar destekli çeviri sürecinde çevirmenin görevi. Turkish Studies-Language and Literature, 14(2), 905-915. 
Tosun, M. (2002). Dil edincini aşan bir edim olarak çeviri eylemi (çeviri kuramlarının gelişiminde paradigma değişimi), Doktora Tezi, İstanbul Üniversitesi Sosyal Bilimler Enstitüsü, İstanbul (yayımlanmamış).

Yazar, U. (2014). "Çeviribilim Bölümlerinde Verilen Derslerin, Özellikle Bilgi Teknolojileri Derslerinin, Çeviri Edinci Kazanılmasına Katkısı” Uluslararası Dil ve Edebiyat Eğitimi Dergisi, Sayı 12, 88-99.

Yazıcı, M. (2005). Çeviribilimin temel kavram ve kuramları. İstanbul: Multilingual.

\section{İnternet kaynakları/Online Resources}

EMT (2009) Competences for professional translators, experts in multilingual and multimedia communication. (Çevrimiçi) https://ec.europa.eu/info/sites/info/files/emt_competences_translators_en.pdf (20 Ağustos 2019)

Hansen, G. (2014) Translationskompetenz: Woher kommt sie und was ist das? (Çevrimiçi) https://gydehansen. $\mathrm{dk} /$ media/2378/translationskompetenz-woher-kommt-sie-und-was-ist-das.pdf (16 Temmuz 2019)

Kościałkowska-Okońska, Ewa (2016) Implacations of translation competence in the legal context: a didactic perkspective (Çevrimiçi) https://pdfs.semanticscholar.org/4620/ee0227ble104964022008ff89f594fe43f9e. pdf (1 Eylül 2019)

Krüger, R \& Serrano Piqueras, J. (2015) Situated Translation in theTranslation Classroom (Çevrimiçi) https:// www.researchgate.net/publication/306039284_Situated_Translation_in_the_Translation_Classroom (10 Temmuz 2019)

Meyer, S. (2009) Wissensmanagement in der Translation (Çevrimiçi) http://othes.univie. ac.at/5357/1/2009-06-08_9807568.pdf (9 Temmuz 2019)

\section{Ders İçerikleri/Course Contents}

Ağrı İbrahim Çeçen Üniversitesi Bilgi Paketi, (Çevrimiçi) https://obs.agri.edu.tr/oibs/bologna/start. aspx? $\mathrm{gkm}=0829311003220234456389203664838808389123418432194355753778437840,(10$ Mart 2020).

Amasya Üniversitesi ders içerikleri, (Çevrimiçi) https://ydy.amasya.edu.tr/media/7052/imt-ders-programi-trdonusturuldu.pdf, (10 Mart 2020).

Bartın Üniversitesi programın öğretim paketi, (Çevrimiçi) http://ubys.bartin.edu.tr/AIS/OutcomeBasedLearning/ Home/Index?id=512\#, (10 Mart 2020).

Boğaziçi Üniversitesi ders içerikleri, (Çevrimiçi) http://www.boun.edu.tr/tr_TR/Content/Akademik/Lisans_ Katalogu/FenEdebiyat_Fakultesi/Ceviribilim_Bolumu, (10 Mart 2020)

Dokuz Eylül Üniversitesi ders yapısı ve kredileri, (Çevrimiçi) http://debis.deu.edu.tr/ders-katalog/2019-2020/ tr/bolum_9814_tr.html, (10 Mart 2020).

Ege Üniversitesi Almanca Mütercim Tercümanlık ders içerikleri, (Çevrimiçi) https://translation.ege.edu.tr/ tr-4827/almanca_mutercim-tercumanlik_lisans_programi.html, (11 Mart 2020.

Ege Üniversitesi İngilizce Mütercim Tercümanlık ders içerikleri, (Çevrimiçi) https://translation.ege.edu.tr/ tr-4828/ingilizce_mutercim-tercumanlik_lisans_programi.html, (11 Mart 2020),

Hacettepe Üniversitesi ders içerikleri, (Çevrimiçi) http://www.mtb.hacettepe.edu.tr/, (11 Mart 2020).

İstanbul Üniversitesi Fransızca Mütercim Tercümanlık ders içerikleri, (Çevrimiçi) http://ebs.istanbul.edu.tr/ home/program?id=1131, (11 Mart 2020).

İstanbul Üniversitesi İngilizce Mütercim Tercümanlık ders içerikleri, (Çevrimiçi) http://ebs.istanbul.edu.tr/ home/program?id=1131, (11 Mart 2020). 
Kırıkkale Üniversitesi Mütercim Tercümanlık bölümleri ders içerikleri, (Çevrimiçi) https://obs.kku.edu.tr/ oibs/bologna/, (11 Mart 2020).

Mardin Artuklu Üniversitesi ders içerikleri, (Çevrimiçi) https://obs.artuklu.edu.tr/oibs/bologna/start. aspx?gkm=01483331532220322003110134480229232194389203111238960, (11 Mart 2020).

Mersin Üniversitesi ders içerikleri, (Çevrimiçi) http://oibs.mersin.edu.tr/bologna/?id=/ course\&program $=156 \& \operatorname{sinif}=3 \&$ sb_id $=539572$, (11 Mart 2020).

Siirt Üniversitesi ders içerikleri, (Çevrimiçi) http://mutercimtercumanen.siirt.edu.tr/, (11 Mart 2020).

Trakya Üniversitesi ders içerikleri, (Çevrimiçi) https://edebiyat.trakya.edu.tr/akademik-yapi/mutercimtercumanlik-bolumu/\#.WeX2oY9-rcs, (11 Mart 2020). 


\section{EK 1. 2019-2020 Ösym Tercih Klavuzundan Öğrenci Alımı Yapan Çeviribilim/ Mütercim Tercümanlık Lisans Programları}

ADANA ALPARSLAN TÜRKEŞ BİLIM VE TEKNOLOJI ÜNIVERSITTESİ (Devlet Üniversitesi) Mütercim-Tercümanlık (İngilizce)

AĞRI İBRAHIM ÇEÇEN ÜNIVERSITESİ (Devlet Üniversitesi)

Mütercim-Tercümanlık (İngilizce)

AMASYA ÜNIVERSITESİ (Devlet Üniversitesi)

Mütercim-Tercümanlık (İngilizce)

ANKARA YILDIRIM BEYAZIT ÜNIVERSITTESİ (Devlet Üniversitesi)

Mütercim-Tercümanlık (Arapça)

Mütercim-Tercümanlık (İngilizce)

ATILIM ÜNIVERSITESİ (ANKARA) (Vakıf Üniversitesi)

Mütercim-Tercümanlık (İngilizce)

BARTIN ÜNIVERSITTESİ (Devlet Üniversitesi)

Çeviribilim (İngilizce)

BAŞKENT ÜNIVERSITESİ (ANKARA) (Vakıf Üniversitesi)

Mütercim-Tercümanlık (İngilizce)

BEYKENT ÜNIVERSITTESİ (İSTANBUL) (Vakıf Üniversitesi)

Mütercim-Tercümanlık (İngilizce)

Mütercim-Tercümanlık (Rusça)

BOĞAZİÇİ ÜNIVERSITTESİ (İSTANBUL) (Devlet Üniversitesi)

Çeviribilim (İngilizce)

BOLU ABANT İZZET BAYSAL ÜNIVERSITTESI (Devlet Üniversitesi)

Mütercim-Tercümanlık (İngilizce)

ÇAĞ ÜNIVERSITESİ (MERSIN) (Vakıf Üniversitesi)

Mütercim-Tercümanlık (İngilizce)

ÇANKAYA ÜNIVERSITESİ (ANKARA) (Vakıf Üniversitesi)

Mütercim-Tercümanlık (İngilizce)

DOĞUŞ ÜNIVERSITESİ (İSTANBUL) (Vakıf Üniversitesi)

Mütercim-Tercümanlık (İngilizce)

DOKUZ EYLÜL ÜNIVERSITESI

Mütercim-Tercümanlık (Almanca)

Mütercim-Tercümanlık (İngilizce) 
EGE ÜNIVERSITESİ (İZMIR) (Devlet Üniversitesi)

Mütercim-Tercümanlık (Almanca)

Mütercim-Tercümanlık (İngilizce)

HACETTEPE ÜNIVERSITTESİ (ANKARA) (Devlet Üniversitesi)

Mütercim-Tercümanlık (Almanca)

Mütercim-Tercümanlık (Fransızca)

Mütercim-Tercümanlık (İngilizce)

HALIÇ ÜNIVERSITESİ (İSTANBUL) (Vakıf Üniversitesi)

Mütercim-Tercümanlık (İngilizce)

İHSAN DOĞRAMACI BİLKENT ÜNIVERSITESİ (ANKARA) (Vakıf Üniversitesi)

Mütercim-Tercümanlık (İng-Fra-Türkçe)

İSTANBUL 29 MAYIS ÜNIVERSITESİ (Vakıf Üniversitesi)

Mütercim-Tercümanlık (Arapça)

Mütercim-Tercümanlık (İngilizce)

İSTANBUL AREL ÜNIVERSITTESİ (Vakıf Üniversitesi)

Mütercim-Tercümanlık (İngilizce)

İSTANBUL AYDIN ÜNIVERSİTESİ (Vakıf Üniversitesi)

Mütercim-Tercümanlık (Arapça)

Mütercim-Tercümanlık (İngilizce)

Mütercim-Tercümanlık (Rusça)

İSTANBUL GELIŞi̇M ÜNIVERSITESİ (Vakıf Üniversitesi)

Mütercim-Tercümanlık (İngilizce)

İSTANBUL OKAN ÜNIVERSITESİ (Vakıf Üniversitesi)

Mütercim-Tercümanlık (Arapça)

Mütercim-Tercümanlık (Çince)

Mütercim-Tercümanlık (İngilizce)

Mütercim-Tercümanlık (Rusça)

İSTANBUL ŞEHIR ÜNIVERSITTESİ (Vakıf Üniversitesi)

Mütercim-Tercümanlık (İngilizce)

İSTANBUL ÜNIVERSITESİ (Devlet Üniversitesi)

Mütercim-Tercümanlık (Almanca)

Mütercim-Tercümanlık (Fransızca)

Mütercim-Tercümanlık (İngilizce)

İSTANBUL YENİ YÜZYIL ÜNIVERSİTESİ (Vakıf Üniversitesi)

Mütercim-Tercümanlık (İngilizce)

İSTINYE ÜNIVERSITTESİ (İSTANBUL) (Vakıf Üniversitesi)

Mütercim-Tercümanlık (İngilizce) 
İZMIR EKONOMI ÜNIVERSITESİ (Vakıf Üniversitesi)

Mütercim-Tercümanlık (İngilizce)

KAFKAS ÜNIVERSITESİ (KARS) (Devlet Üniversitesi)

Mütercim-Tercümanlık (Türkçe/İngilizce/Fransızca)

KAPADOKYA ÜNIVERSITESİ (NEVŞEHİR) (Vakıf Üniversitesi)

Mütercim-Tercümanlık (İngilizce)

KARAMANOĞLU MEHMETBEY ÜNIVERSITESİ (KARAMAN) (Devlet Üniversitesi)

Mütercim-Tercümanlık (Almanca)

Mütercim-Tercümanlık (Arapça)

KIRIKKALE ÜNIVERSITESİ (Devlet Üniversitesi)

Mütercim-Tercümanlık (Arapça)

Mütercim-Tercümanlık (Farsça)

Mütercim-Tercümanlık (Fransızca)

Mütercim-Tercümanlık (İngilizce)

KIRKLARELI ÜNIVERSITTESİ (Devlet Üniversitesi)

Mütercim-Tercümanlık (İngilizce) alım olmamış hiç

KTO KARATAY ÜNIVERSITESİ (KONYA) (Vakıf Üniversitesi)

Mütercim-Tercümanlık (Arapça)

Mütercim-Tercümanlık (İngilizce)

KÜTAHYA DUMLUPINAR ÜNIVERSITESİ (Devlet Üniversitesi)

Mütercim-Tercümanlık (İngilizce) alım yapmamış

MANISA CELÂL BAYAR ÜNIVERSITESİ (Devlet Üniversitesi)

Mütercim-Tercümanlık (İngilizce) puanlar yok

MARDIN ARTUKLU ÜNIVERSITESİ (Devlet Üniversitesi)

Mütercim-Tercümanlık (İngilizce)

MARMARA ÜNIVERSITESİ (İSTANBUL) (Devlet Üniversitesi)

Mütercim-Tercümanlık (Almanca)

Mütercim-Tercümanlık (Fransızca)

Mütercim-Tercümanlık (İngilizce)

MERSIN ÜNIVERSITESİ (Devlet Üniversitesi)

Mütercim-Tercümanlık (Almanca)

Mütercim-Tercümanlık (Fransızca)

MUĞLA SITKI KOÇMAN ÜNIVERSITESİ (Devlet Üniversitesi)

Mütercim-Tercümanlık (İngilizce) hiç alım yapmamış

SAKARYA ÜNIVERSITESİ (Devlet Üniversitesi)

Çeviribilim (Almanca) 
SELÇUK ÜNIVERSITTESİ (KONYA) (Devlet Üniversitesi)

Mütercim-Tercümanlık (Arapça)

Mütercim-Tercümanlık (İngilizce)

SIİRT ÜNIVERSITTESİ (Devlet Üniversitesi)

Mütercim-Tercümanlık (İngilizce)

SIVAS CUMHURIYET ÜNIVERSITESİ (Devlet Üniversitesi)

Mütercim-Tercümanlık (İngilizce, Fransızca, Türkçe)

TOROS ÜNIVERSITESİ (MERSIN) (Vakıf Üniversitesi)

Mütercim-Tercümanlık (İngilizce)

TRAKYA ÜNIVERSITESİ (EDİRNE) (Devlet Üniversitesi)

Mütercim-Tercümanlık (Almanca)

Mütercim-Tercümanlık (Bulgarca)

Mütercim-Tercümanlık (İngilizce)

YAŞAR ÜNIVERSITESİ (İZMIR) (Vakıf Üniversitesi)

Mütercim-Tercümanlık (İngilizce)

YEDITTEPE ÜNIVERSITTESİ (İSTANBUL) (Vakıf Üniversitesi)

Çeviribilim (İngilizce)

YILDIZ TEKNİK ÜNIVERSİTESİ (İSTANBUL) (Devlet Üniversitesi)

Mütercim-Tercümanlık (Fransızca) 